University of San Diego

Digital USD

2014-04-01

\title{
Relationship between Participation in Nurse Externship Program and RN Retention and Quality Care
}

Lourdes C. Salandanan PhD

University of San Diego

Follow this and additional works at: https://digital.sandiego.edu/dissertations

Part of the Nursing Commons

\section{Digital USD Citation}

Salandanan, Lourdes C. PhD, "Relationship between Participation in Nurse Externship Program and RN Retention and Quality Care" (2014). Dissertations. 462.

https://digital.sandiego.edu/dissertations/462

This Dissertation: Open Access is brought to you for free and open access by the Theses and Dissertations at Digital USD. It has been accepted for inclusion in Dissertations by an authorized administrator of Digital USD. For more information, please contact digital@sandiego.edu. 
Relationship Between Participation in a Nurse Externship Program and RN Retention and Quality Care

Lourdes Salandanan

University of San Diego

Linda D. Urden

April 11, 2014 


\title{
UNIVERSITY OF SAN DIEGO
}

Hahn School of Nursing and Health Science

DOCTOR OF PHILOSOPHY OF NURSING

\section{RELATIONSHIP BETWEEN PARTICIPATION IN NURSE EXTERNSHIP PROGRAM AND RN RETENTION AND QUALITY CARE}

\section{By}

Lourdes C. Salandanan

A dissertation presented to the

FACULTY OF THE HAHN SCHOOL OF NURSING AND HEALTH SCIENCE UNIVERSITY OF SAN DIEGO

\author{
In partial fulfillment of the \\ requirements for the degree \\ DOCTOR OF PHILOSOPHY IN NURSING
}

April 2014

\section{DISSERTATION COMMITTEE}

Linda D. Urden, DNSc, RN, CNS, NE-BC, FAAN, Chairperson

Lucia Gonzales, PhD, MBA, MSN, RN, Committee Member

Marcia Faller, $\mathrm{PhD}, \mathrm{RN}$, Committee Member 
(C) Copyright by Lourdes C. Salandanan

All Rights Reserved 2014 


\section{Table of Contents}

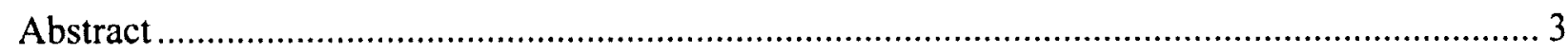

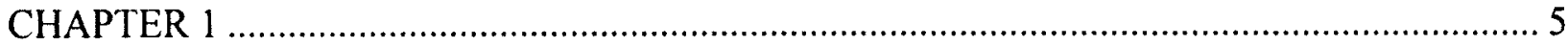

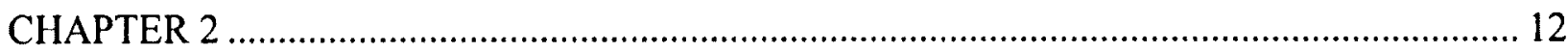

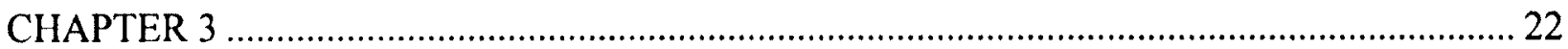

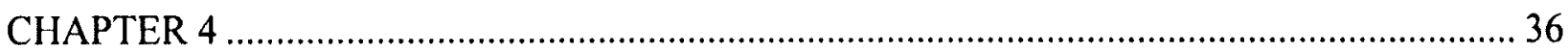

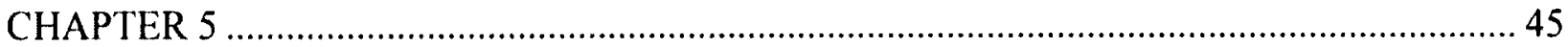

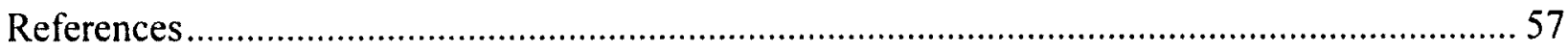




\begin{abstract}
Study Background. Nurse externship programs were initially developed by healthcare institutions as a recruitment tool for new nurses. Literature has demonstrated the positive outcomes of the program on the participants and healthcare institutions but during times of economic difficulties, health care institutions discontinue the program. The studies that demonstrate the value of the program are limited to the recruitment phase and the 2-year retention of the newly graduated nurses. There is a need to demonstrate the value of the program in terms quality of care and long term $\mathrm{RN}$ retention.
\end{abstract}

Research Questions. The three research questions this study addressed include:

(1) What is the relationship between student nurse externship experience and extension of the new graduate, unit-based orientation?

(2) What is the relationship between student nurse externship experience and working full time over the first 5 years of employment?

(3) What is the relationship between student nurse externship experience and adherence to select quality care indicators?

Study Aims. The aims of this study were:

(1) Determine the relationships between nursing student externship,
a. extension of new graduate, unit-based orientation and
b. working full time over the first 5 years of employment.

(2) Determine the relationship between nurse externship and adherence to select quality care indicators:
a. Acute myocardial infarction (AMI);
b. Heart failure (HF); 
c. Pneumonia;

d. Surgical Care Improvement Project (SCIP);

e. Outpatient Department;

f. Emergency Department;

g. Immunization;

h. Stroke; and

i. Venous Thrombosis.

(3) Develop a ROI formula that can be utilized to explain the cost effectiveness of a nurse externship program.

Study Methods. A data collection tool was developed and used to review human resources, education, payroll, and performance improvement files. The data were analyzed using a nonexperimental, retrospective, descriptive, correlational, statistical design. Mean square contingency, also known as phi coefficient, was used to test the correlational of the two groups: (1) new grad RNs with nurse externship experience and (2) new grad RNs with no nurse externship experience.

Conclusion. The findings were used to develop a ROI formula for the program. The ROI may be used by other institutions to explain both the cost effectiveness of the program and its existence. There is a significant, negative correlation between nurse externship experience and extension of unit-based orientation. No significant correlation was found between nurse externship experience and 5-year full time employment and adherence to quality indicators. Data analysis revealed the average extension length of time for unit-based orientation is 100 hours. The cost benefit of this program for the sample is $\$ 211,200$ and the computed $\mathrm{ROI}$ is $135 \%$. 


\section{CHAPTER 1}

The purpose of this study was to develop a ROI formula that can be utilized to explain the value and cost effectiveness of a nurse externship program in health care facilities.

Background. Nurse extern programs offer nursing students opportunities to develop clinical skills prior to graduation and entering the work force as licensed and professional registered nurses (RNs). They were initially developed by healthcare institutions as an effort to recruit and retain RNs during periods of nursing shortages. Studies have demonstrated the advantage of the program on students (Ruth-Sahd, Beck, \& McCall, 2010; Starr \& Conley, 2006). Several studies demonstrate the immediate benefits of the program for both the students and the healthcare institutions' recruitment and retention efforts (Cantrell \& Browne, 2005; Cantrell \& Browne, 2006; Cantrell, Browne, \& Lupinacci, 2005; Hoffart, Waddell, \& Young, 2011; Lott, Willis, \& Lyttle, 2011).

Researchers have suggested nurse extern programs provide participants with a realitybased image of nursing practice and maintain a more realistic perspective of the ideal professional nursing practice compared to the controls during the study (Cantrell et al., 2005; (Ruth-Sahd et al., 2010; Starr \& Conley, 2006). Research has also been published about the effects of externship on the socialization of the RNs into their new roles (Lott et al., 2011; RuthSahd et al., 2010; Starr \& Conley, 2006). In a study of the effects of the program on the ease of transition of the student to the RN role, Steen, Gould, Reingruber, and Hill, (2011) found internship programs significantly contribute to the success of the new graduate nurses. The study focused on the period immediately following employment. No studies have evaluated the longterm effects of the program and yet the first 5 years in the nursing profession is crucial. A 5-year longitudinal, qualitative study by the National Council of State Boards of Nursing (2009) found 
during their second and third years of practice, new RNs were still gaining confidence in clinical decision making, communicating with physicians, and initiating care.

Although earlier studies addressed the recruitment and early retention effects of a nurse extern program, only one included a cost savings analysis. The third of a 3-part study by Cantrell \& Browne (2006) concluded the cost savings in recruitment of new nurses but not in long-term retention. There are no studies demonstrating the long-term effects of the program, beyond 2 years, on both the students who have become registered nurses (RNs) and the healthcare institution in which they practiced. Beecroft, Kunzman, and Krozek (2001) examined the cost effectiveness of $\mathrm{RN}$ residency programs, a form of new nurse transition programs that starts after licensure and employment. The existence of such well-grounded literature has helped nursing professional developers (NPDs) and nursing administrators justify the existence of residency programs in their organization. The same type of literature is needed to explain the continued existence of nurse externship programs.

Nursing professional developers (NPDs) have learned the importance of utilizing return on investment (ROI) formulas to support the effectiveness of the various educational programs they develop, implement, evaluate, and maintain. Staff development programs constitute costs that include both labor and material expenses (Buerhaus, Auerbach, \& Staiger, 2009). As good stewards of their organizations, NPDs are expected to monitor the cost and outcomes of their educational programs. Established ROI formulas can assist NPDs in evaluating the outcomes of a program to hospital administrators whose perspective includes both ROI and quality patient outcomes. The purpose of this study is to develop a ROI formula that can be utilized to explain value and cost effectiveness of a nurse externship program in health care facilities. 
Problem. Nurse externship programs were initially developed by healthcare institutions as a recruitment tool for new nurses. Literature has reported the positive outcomes of the program on the participants but during times of economic difficulties, health care institutions discontinue the program. Stuudies demonstrating the financial impact of the program are limited to the recruitment phase and the 2-year retention of the nurses. There is a need to demonstrate the long-term value of the program related to quality care indicators, retention, and return on investment (ROI).

Purpose. Nursing professional developers (NPDs) have learned the importance of utilizing return on investment (ROI) formulas to support the effectiveness of the various educational programs they develop, implement, evaluate, and maintain. Staff development programs constitute costs that include both labor and material expenses (Buerhaus, Auerbach, \& Staiger, 2009). As good stewards of their organizations, NPDs are expected to monitor the cost and outcomes of their educational programs. Established ROI formulas can assist NPDs in evaluating the outcomes of a program to hospital administrators whose perspective includes both $\mathrm{ROI}$ and quality patient outcomes. The purpose of this study was to develop a ROI formula that can be utilized to explain the existence and cost effectiveness of a nurse externship program in health care facilities.

Framework. The conceptual framework that guided this study is the ROI Methodology ${ }^{\mathrm{TM}}$ (Phillips, 1977) and is depicted in Figure 1. It includes 5 levels of data and describes each measurement focus. The model includes evaluation phases also described in Kirkpatrick's 4 levels of educational program evaluation model (Kirkpatrick, 1998) and goes beyond Kirkpatrick's 4 levels by adding another type of data: monetary data. 
The methodology has been used in a variety of industries including information engineering, technology, academia, human resources, and leadership development. The methodology was especially useful in this study because both the methodology and the study involve a strong element of education and training; both of which are at the center of the model.

The ROI Methodology Model ${ }^{\mathrm{TM}}$ has 2 major phases, the initial analysis phase and the measurement and evaluation phase. The steps of each phase are connected by objectives that progress from an initial, individualized reaction to the project to a long-term and broad-based, organization-wide effect. The broad based, organization-wide effect will ultimately determine the longevity of the existence of the program. The steps that will guide my study the most are the final two steps of the model that are joined by impact objectives and ROI objectives.

At the start of the process, the NPD drills down on the five classes of needs that are: (a) payoff; (b) business; (c) job performance; (d) learner; and (e) preference. The actual "project" developed is based on the aggregated needs. Once having defined the "project," the next phase is to measure and evaluate. The first step in this phase is to measure the participant's reaction. Second step is to measure the learning objectives. Third is to measure the appreciation of the project. Fourth step is to measure the impact and lastly the ROI is measured. Objectives are what "tie" the needs to measurement and evaluation. Each has its own objective: (a) reaction; (b) learning; (c) behavior; (d) impact; and finally (e) return on investment.

The sequence of the needs analysis and the measurement and evaluation is from the left downward and then to the right upward. Arrows in the model denote direction of the process. One develops the "project" objectives starting with the pay off needs and ends with the preference needs. The sequence of measurement of evaluation starts with measuring the learner's reaction first and ends with measuring the pay off need objectives. There is no established 
timeframe to follow the ROI Methodology Model ${ }^{\mathrm{TM}}$. It can occur rapidly or over a lengthy time depending on the "project". For the nurse externship program, the ROI methodology is expected to be a lengthy evaluative process.

The framework depicts a strong element of accountability in program development. Business alignment and forecasting are now necessary skills in program and professional development. Sound judgment and an understanding of existing resources are required to identify business needs and strategically plan for the future of the organization. Businesses and industries are demanding program developers and not only show project impact but also the monetary benefits of the program that will lead to further growth in the business or industry.

A NPD's success is contingent on incorporating training programs as a means to sustain business and not as a final product. As NPDs, it is imperative to hardwire the ROI process for every new program. In so doing, there will be less chances of failure for both the NPDs and the program and it will help the NPD earn a seat at the decision-making table. The ROI Methodology Model ${ }^{\mathrm{TM}}$ is a tool NPDs may utilize in an effort to develop highly successful and sustainable programs such as a nurse extern program. 


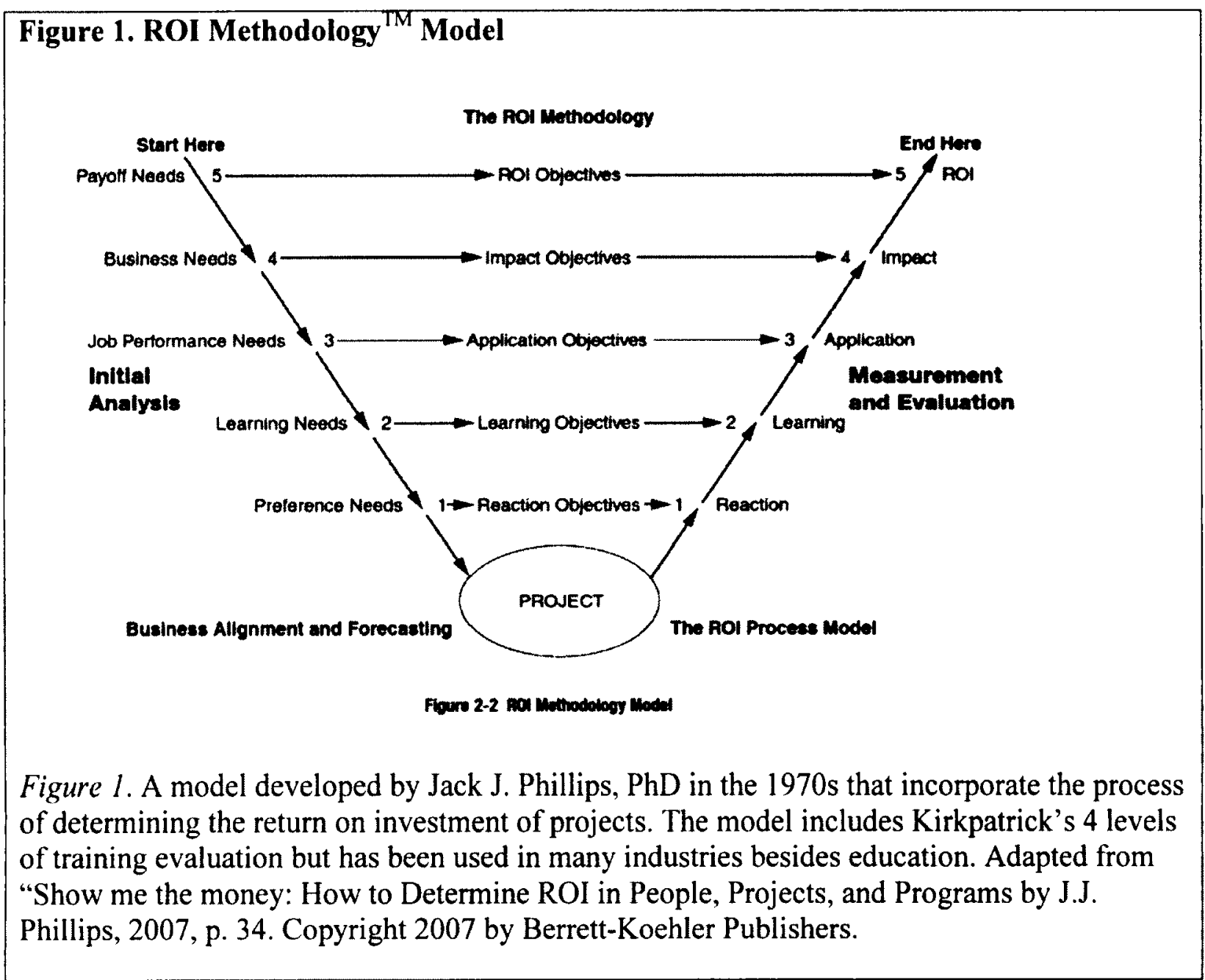

\section{Study Aims.}

Aim 1. Determine the relationships between nursing student externship,

a. extension of new graduate, unit-based orientation and

b. working full time over the first 5 years of employment.

Aim 2. Determine the relationship between nurse externship and adherence to select quality care indicators:

a. Acute myocardial infarction (AMI)

b. Heart failure (HF)

c. Pneumonia 
d. Surgical Care Improvement Project (SCIP)

e. Outpatient Department

f. Emergency Department

g. Immunization

h. Stroke

i. Venous Thrombosis

Aim 3. Develop a ROI formula that can be utilized to explain the cost effectiveness of a nurse externship program.

\section{Research questions.}

Question 1. What is the relationship between student nurse externship experience and extension of the new graduate, unit-based orientation?

Question 2. What is the relationship between student nurse externship experience and working full time over the first 5 years of employment?

Question 3. What is the relationship between nurse externship experience and select patient care quality indicators?

Summary. The purpose of this research was to develop a ROI formula that can be utilized to explain the value and the cost effectiveness of a nurse extern program in health care facilities. The usefulness of a ROI formula is not limited to health care facilities. Coordinating externship programs may also be costly to academic institutions, thus the formula may also be used by nursing faculty to demonstrate the value of the program to their school administrators. 


\section{CHAPTER 2}

The nurse extern program provides both college units and employment opportunities to nursing students who are in good standing in their programs. It provides a one-on-one preceptorship with a registered nurse (RN) for approximately 150 hours at an acute care hospital. The program usually takes place during the winter and summer intercessions when there are less students rotating in the clinical setting thereby allowing the staff nurses to focus on the learning needs of the nurse extern assigned to the unit. Nurse extern programs were originally developed by healthcare institutions in order to recruit and retain nurses during periods of nursing shortages.

Externship offers clinical opportunities for nursing students to practice what they have learned and demonstrated in nursing school. Experiential learning through the program leads to a reality-based perspective of the role of the RN (Ruth-Sahd et al., 2010) and the development of the participant's confidence (Steen et al., 2011). Earlier studies have explored the outcomes as described by senior nursing students and newly graduate nurses. No studies have been published regarding the long-term outcomes of the program on the participants' employment patterns.

Nurse extern programs give student nurses opportunities to develop clinical skills prior to graduation and entering the work force as licensed and professional RNs. The program was meant to bridge identified gaps between the educational and practice settings for nursing. Although the program was initially developed by healthcare institutions as an effort to recruit and retain RNs during periods of nursing shortages they have also been found to be beneficial to the student participants (Stinson \& Wilkinson, 2004; Cantrell \& Browne, 2006; Starr \& Conley, 2006; Kilpatrick \& Frunchak, 2006; Steen et al., 2011; Lott et al., 2011). 
Stinson and Wilkinson (2004) developed, implemented and evaluated a nurse extern program using Dwyer's logic model. The evaluation of the pilot project was very positive and thus the program developers were equipped with information that allowed them to expand the program. The program was expanded from 3 nursing service units, including the emergency department, to a total of 8 . The program expansion also included the expansion of the scope of practice of the externs while continuing to adhere to patient safety.

In an effort to improve the existing student nurse extern program in an acute care facility in South Carolina, Lott, Willis, and Lyttle (2011) collaborated with key individuals in the human resources, nurse management, and nurse education departments. The authors conducted a literature review and interviewed staff developers in nearby hospitals that also have nurse extern programs. The advantages and disadvantages of various program components were reviewed and were therefore considered and contributed to the successful re-design of the program. Key components that were included in the re-design were: (a) removing the student from the staffing matrix; (b) assigning one consistent preceptor to the student for the whole rotation; (c) limiting the program to the summer; (d) standardizing the employment and orientation process; and (e) standardizing the expectations for all the externs. The re-design led to increased satisfaction of the student externs compared to the student externs 3 years prior to the re-design and higher Performance Based Development System (PBDS) (Performance Management Services, Inc., n.d.) Assessment scores compared to non-extern new grad nurses. The PBDS (DelBueno, 2005) is a customized assessment system used in many health care facilities to evaluate the critical thinking, interpersonal, and technical skills.

Starr and Conley (2006) conducted a qualitative study to better understand and document the point of view of the participants in a student nurse extern. The study took place at Yuma 
Regional Medical Center in Arizona where students from Arizona Western Community College are employed as student externs. The authors found that many of the studies that have been conducted thus far by the institutions aimed to identify the institutional outcomes of the program. Contrary to the aims of the previous studies, Starr and Conley (2006) aimed to identify the outcomes from the students' perspective. The students found the program beneficial because students perceived: (a) growth in their competence and confidence; (b) they were part of a team; (c) they learned the role of the professional nurse, and (d) they were moving towards their goal as a professional nurse. The institution and school on the other hand realized the benefits of the program since its foci were changed to learning and socialization into the role of the professional nurse.

As a strategy to address the nursing shortage, Kilpatrick and Frunchak (2006) developed a comprehensive nursing extern program. The program required very supportive managers, educators, and preceptors and several levels of evaluations. It required training and engagement of incumbent staff members who functioned as preceptors. The evaluations included focus groups and questionnaires. The authors found that the experience was very positive for the students and the schools. The institution found the program beneficial because of its positive effects on the staff and the ability to retain $62 \%$ of the students immediately after they received their license.

To study the immediate results of an 8-week summer nurse extern program, Ruth-Sahd, Beck, and McCall (2008) developed multiple phases of program evaluation. Utilizing descriptive, qualitative methodologies including individual discussions, focus groups, and reflective surveys, the authors found three major themes 78 senior nursing students in the 
summer externship program revealed. The themes include: (a) affirming assumptions; (b) validating values; and (c) banishing core beliefs.

Steen, Gould, Reingruber, and Hill (2011) developed a quantitative study to measure the immediate effects of a student nurse extern program on the new graduates' transition into their roles as licensed staff members. Numerous questionnaires were developed and administered to RNs employed at the hospital in which they were formerly employed as student nurse externs. An analysis of the self-assessment surveys of 50 former student externs' period immediately following employment at the facility where they were earlier employed as an extern demonstrated externship programs significantly contribute to the success of the new graduate nurses.

Cantrell published a 3-part series to investigate the outcomes of a summer nurse extern program. The series include a quantitative, qualitative, and finally a recruitment and retention evaluation of the program. In the first part of the series, Cantrell, Brown, and Lupinacci (2005), used quantitative methods to evaluate the effects of the program 2 years after licensure and employment at an acute care facility. The authors compared a group of 26 former externs and a matched cohort group of 26 who did not participate in a nurse extern program. No statistically significant differences were found between the two groups on the variables of job satisfaction and sense of belonging, however, the group who did not participate in externship demonstrated a statistically significant higher average in professionalism and role socialization than those who participated in externship.

In the second part of the series, Cantrell and Brown (2005) conducted a focus group interview with $6 \mathrm{RNs}$ who participated in a summer nurse extern program 1 to 2 years prior to the interview. The 3 themes that emerged from the analysis of the findings include: (1) being a 
part of the real scene; (2) figuring out the environment; and (3) gaining awareness and becoming frightened. They concluded that the professional and personal growth through experiential learning as an extern is significant.

In the third part of the series, Cantrell and Brown (2006) reported the recruitment and retention benefits of the program. The authors reported a recruitment rate of $79 \%$ of externs immediately after licensure, $77 \%$ retention after a year of employment, and $61 \%$ of retention after two years of employment. The authors concluded the program to be an effective recruitment and 2-year retention program for the institution that sponsored a nurse extern program.

Anecdotal data and studies demonstrate the benefits of the program for the participants. Researchers have suggested that nurse extern programs produce new graduates with a realitybased image of nursing practice and maintain a more realistic perspective of the ideal professional nursing practice compared to the controls during the study (Cantrell et al., 2005; Kilpatrick \& Frunchak, 2006; Ruth-Sahd et al., 2010; Starr \& Conley, 2006; Steen et al., 2011 ).

Research has also been published about the effects of externship on the socialization of the RNs into their new roles (Ruth-Sahd et al., 2010; Starr \& Conley, 2006). In a self-assessment survey of the effects of the program on the ease of transition of the student to the RN role, Steen, Gould, Reingruber, and Hill (2011) found nurse extern programs may significantly contribute to the success of the new graduate nurses. The study focused on the self-assessment survey of 50 former student externs' period immediately following employment at the facility where they were earlier employed as an extern.

On the contrary, Cantrell, Brown, and Lupinacci (2005), in the first part of a 3-part series of articles demonstrated the negative impact the nurse extern program had on the professionalism 
and role socialization of the new RN. The authors compared two groups of RNs: a group of RNs who had participated in an externship and a matched cohort group of RNs who had not participated in an externship program at any clinical agency. The sample size of 56 had an equal number of participants in each group. The instruments used by the authors include the: (1) Nursing Activity Scales, (2) Nurses Self-Description Form, (3) Sense of Belonging Instrument, and (4) McCloskey/Mueller Satisfaction Scale.

The authors expected the number of years of experience as an $\mathrm{RN}$ may influence the measurement on all 4 variables. Thus the average number of years of experience for each pairing was used as the covariate for the ANCOVA procedure. No statistical difference was found between the cohorts on the variables of job satisfaction and sense of belonging. In contrast, the analysis demonstrated significant differences in the mean scores for professionalism and role socialization. Between the two cohorts, the average score on each scale for those nurses in the cohort group was higher as compared to the average scale score of the nurses who had participated in a nurse extern program.

No studies have evaluated the long-term effects of the nurse extern program and yet a 5year longitudinal, qualitative study by the National Council of State Boards of Nursing (2009) demonstrated that during their second and third years of practice, new RNs were still gaining confidence in clinical decision making, communicating with physicians, and initiating care.

Although the earlier studies addressed the recruitment and early retention effects of a nurse extern program only a limited number of the studies included a cost savings analysis. Cantrell and Browne in 2006 published the third of a 3-part study of in which the authors concluded the cost savings in recruitment of new nurses but not long-term retention. 
Pine and Tart (2007) evaluated a residency program using a ROI formula and turnover rate thus demonstrating a marked savings related to retention rates and decrease vacancies. The survey description along with the methodology used was not clearly defined in the publication. However, literature (Beecroft, Dorey, \& Wenten, 2008) exists about the cost effectiveness of RN residency programs, a form of new nurse transition programs that starts after licensure and employment. The existence of such well-grounded, comprehensive studies has helped NPDs and nursing administrators explain the existence of residency programs in their organization. The same type of literature is needed to explain the continued existence of nurse externship programs.

Summary. Earlier studies of the outcomes of nurse externship programs, as shown in Table 1, have consistently shown initial effects of the program such as its effects on career development for the participants both as students and as new RNs. The studies have also demonstrated the short-term advantage of the program as both a recruitment and 2-year retention tool for the hospitals. There is a need to expand the knowledge surrounding the nurse extern program by studying its long-term effects on employment and quality of patient care. This study gives us a better understanding of the value of the nurse extern program to the hospital and may lend to program sustainability. 
Table 1.

Summary of Studies Related to Nurse Extern Programs

\begin{tabular}{|c|c|c|c|c|c|c|}
\hline & Authors & $\begin{array}{c}\text { Design / } \\
\text { Conceptual } \\
\text { Framework }\end{array}$ & Sample & $\begin{array}{c}\text { Intervention \& } \\
\text { Measurement Tools }\end{array}$ & Findings & Comments \\
\hline 1 & $\begin{array}{l}\text { Cantrell } \\
\text { Browne } \\
\text { Lupinacci } \\
(2005) \# 1\end{array}$ & $\begin{array}{l}\text { Godinez } \\
\text { Theoretical } \\
\text { Framework } \\
\text { (1999) } \\
\text { Quantitative } \\
\text { study }\end{array}$ & $\begin{array}{l}\text { Matched } \\
\text { comparison } \\
\text { of } 2 \text { groups: } \\
26 \text { who } \\
\text { participated } \\
\text { in externship } \\
\text { and } 26 \text { who } \\
\text { did not } \\
\text { participate }\end{array}$ & $\begin{array}{l}\text { Nursing Activity Scales } \\
\text { (Professionalism); } \\
\text { Nurses Self-Direction } \\
\text { From (role } \\
\text { socialization); Sense of } \\
\text { Belonging Instrument } \\
\text { (Sense of Belonging); } \\
\text { and McCloskey/ } \\
\text { Mueller Satisfaction } \\
\text { Scale (Job Satisfaction) }\end{array}$ & $\begin{array}{l}\text { No difference in job } \\
\text { satisfaction \& job } \\
\text { satisfaction; non-externs } \\
\text { had higher professionalism } \\
\text { and role socialization } \\
\text { scores }\end{array}$ & $\begin{array}{l}\text { Results may be related to } \\
\text { nature of the magnet } \\
\text { institution where they } \\
\text { worked at. }\end{array}$ \\
\hline 2 & $\begin{array}{l}\text { Cantrell } \\
\text { Browne } \\
(2005) \# 2\end{array}$ & $\begin{array}{l}\text { Godinez } \\
\text { Theoretical } \\
\text { Framework, } \\
\text { Qualitative, } \\
\text { longitudinal } \\
\text { grounded } \\
\text { theory }\end{array}$ & 6 participants & Focus Groups & $\begin{array}{l}\text { Themes: being part of the } \\
\text { real scene; figuring out the } \\
\text { environment; gaining } \\
\text { awareness \& becoming } \\
\text { frightened. Frightened b/c } \\
\text { of early exposure to the } \\
\text { clinical areas. This is an } \\
\text { early realization to the } \\
\text { reality of the nursing } \\
\text { career. }\end{array}$ & $\begin{array}{l}\text { Low generalizability } \mathrm{b} / \mathrm{c} \\
\text { only } 6 \text { participants. } \\
\text { Importance of mastery of } \\
\text { environment to focus on } \\
\text { new learnings }\end{array}$ \\
\hline 3 & $\begin{array}{l}\text { Cantrell } \\
\text { Browne } \\
(2006) \# 3\end{array}$ & $\begin{array}{l}\text { Godinez } \\
\text { Theoretical } \\
\text { Framework, } \\
\text { Review of } \\
\text { employment } \\
\text { history } \\
\text { records }\end{array}$ & 193 externs & $\begin{array}{l}\text { Review of employment } \\
\text { from } 1998-2003\end{array}$ & $\begin{array}{l}79 \% \text { of externs were hired; } \\
\text { turnover rate reflected } \\
\text { other RNs within the } \\
\text { hospital }\end{array}$ & Effective recruitment tool \\
\hline
\end{tabular}




\begin{tabular}{|c|c|c|c|c|c|c|}
\hline 4 & $\begin{array}{l}\text { Hoffart } \\
\text { Waddell } \\
\text { Young } \\
(2011)\end{array}$ & $\begin{array}{l}\text { Comprehen- } \\
\text { sive review of } \\
\text { existing of } \\
\text { NNTP } \\
\text { research } \\
\text { studies }\end{array}$ & $\begin{array}{l}\text { Published } \\
\text { researched } \\
\text { studies }\end{array}$ & Comprehensive Review & $\begin{array}{l}\text { Developed their own } \\
\text { NNTP theoretical } \\
\text { framework }\end{array}$ & $\begin{array}{l}\text { Can we test this by using } \\
\text { specific variables }\end{array}$ \\
\hline 5 & $\begin{array}{l}\text { Kilpatrick, } \\
\text { K., } \\
\text { Frunchak, } \\
\text { V. (2006) }\end{array}$ & $\begin{array}{l}\text { No } \\
\text { framework }\end{array}$ & Unclear & $\begin{array}{l}\text { Focus groups: externs, } \\
\text { preceptors, mentors }\end{array}$ & $\begin{array}{l}\text { Early exposure promotes } \\
\text { appreciates of the } \\
\text { organization and } \\
\text { functioning of the unit, } \\
\text { facilitate application of } \\
\text { knowledge and acquisition } \\
\text { of nursing skills, engage } \\
\text { motivated students. } 62 \% \\
\text { retained as staff. }\end{array}$ & $\begin{array}{l}\text { Unclear number of } \\
\text { informants }\end{array}$ \\
\hline 6 & $\begin{array}{l}\text { Lott } \\
\text { Willis } \\
\text { Lyttle } \\
(2011)\end{array}$ & $\begin{array}{l}\text { Comparison } \\
\text { of retention } \\
\text { rate }\end{array}$ & $\begin{array}{l}\text { Participants } \\
\text { of nurse } \\
\text { extern } \\
\text { program }\end{array}$ & $\begin{array}{l}\text { Comparison of } \\
\text { retention rates of nurses } \\
\text { before and after a } \\
\text { change in program }\end{array}$ & $\begin{array}{l}\text { Improved orientation and } \\
\text { mentorship increased the } \\
\text { retention of externs but not } \\
\text { necessarily the nurse extern } \\
\text { program. }\end{array}$ & $\begin{array}{l}\text { Keep externs out of } \\
\text { staffing, provide } \\
\text { consistency of preceptor, } \\
\text { standardize the role }\end{array}$ \\
\hline 7 & $\begin{array}{l}\text { Pine } \\
\text { Tart } \\
(2007)\end{array}$ & $\begin{array}{l}\text { Dreyfus Skill } \\
\text { Acquisition as } \\
\text { described by } \\
\text { Benner }\end{array}$ & Unclear & $\begin{array}{l}\text { Program evaluation } \\
\text { including ROI, } \\
\text { turnover rate }\end{array}$ & $\begin{array}{l}\text { ROI calculation } \\
\text { demonstrate the marked } \\
\text { savings } r / t \text { retention rates, } \\
\text { decrease vacancies }\end{array}$ & $\begin{array}{l}\text { Unclear surveys, unclear } \\
\text { methodology }\end{array}$ \\
\hline 8 & $\begin{array}{l}\text { Ruth-Sahd } \\
\text { Beck } \\
\text { McCall } \\
(2010)\end{array}$ & $\begin{array}{l}\text { Descriptive, } \\
\text { qualitative } \\
\text { study }\end{array}$ & $\begin{array}{l}78 \text { nursing } \\
\text { students, } \\
\text { various } \\
\text { nursing } \\
\text { degrees who } \\
\text { participated } \\
\text { in summer } \\
\text { externship } \\
\text { program }\end{array}$ & $\begin{array}{l}\text { Open-ended survey } \\
\text { questions throughout } \\
\text { the program. Surveys } \\
\text { sent at the end of the } \\
\text { program. }\end{array}$ & $\begin{array}{l}3 \text { major themes - validating } \\
\text { values, affirming } \\
\text { assumptions, banishing } \\
\text { some core beliefs }\end{array}$ & $\begin{array}{l}\text { Practicing nurses have } \\
\text { significant impact on } \\
\text { attitudes and professional } \\
\text { development of future } \\
\text { nurses. Focus on students } \\
\text { and not RNs yet. }\end{array}$ \\
\hline
\end{tabular}




\begin{tabular}{|c|c|c|c|c|c|c|}
\hline 9 & $\begin{array}{l}\text { Starr } \\
\text { Conley } \\
(2006)\end{array}$ & $\begin{array}{l}\text { Qualitative } \\
\text { study \& } \\
\text { interview } \\
\text { research }\end{array}$ & $\begin{array}{l}10 \text { of the } 16 \\
\text { externs, } \\
\text { female, } 21- \\
60 \text { years old }\end{array}$ & $60-90 \mathrm{~min}$ interview & $\begin{array}{l}3 \text { key points }-1 \text { ) growth; } 2 \text { ) } \\
\text { team member; } 3 \text { ) beneficial } \\
\text { for both student and } \\
\text { institution }\end{array}$ & $\begin{array}{l}\text { Helpful information for } \\
\text { the development and } \\
\text { improvement of } \\
\text { programs }\end{array}$ \\
\hline 10 & $\begin{array}{l}\text { Steen, } \\
\text { Gould, } \\
\text { Reingrub- } \\
\text { er, Hill } \\
(2011)\end{array}$ & $\begin{array}{l}\text { Benner, } \\
\text { quantitative } \\
\text { research; TJC } \\
\text { in } 2002 \\
\text { symposium } \\
\text { addressed } \\
\text { "continental } \\
\text { divide } \\
\text { between } \\
\text { nursing } \\
\text { education and } \\
\text { nursing } \\
\text { practice } \\
\text { creates } \\
\text { perception } \\
\text { that a new } \\
\text { grad lacks } \\
\text { nursing } \\
\text { competency" }\end{array}$ & $\begin{array}{l}50 \text { subjects, } \\
\text { former } \\
\text { interns who } \\
\text { were hired at } \\
\text { hospitals }\end{array}$ & Surveys & $\begin{array}{l}\text { Familiarity helped in } \\
\text { transition, increased } \\
\text { confidence in performing } \\
\text { tasks. Those who remained } \\
\text { in the unit where the } \\
\text { interned felt more pressure } \\
\text { than those who moved to } \\
\text { another unit. }\end{array}$ & $\begin{array}{l}\text { Focus on self- } \\
\text { assessment; transition } \\
\text { pressures on self }\end{array}$ \\
\hline 11 & $\begin{array}{l}\text { Stinson } \\
\text { Wilkinson } \\
(2004)\end{array}$ & $\begin{array}{l}\text { Logic Model; } \\
\text { used in } \\
\text { developing an } \\
\text { externship } \\
\text { program }\end{array}$ & $\begin{array}{l}\text { Externs in } \\
\text { the program; } \\
\text { preceptors; } \\
\text { directors }\end{array}$ & $\begin{array}{l}\text { Questionnaires for } \\
\text { preceptors and students }\end{array}$ & $\begin{array}{l}\text { Use of logic model helped } \\
\text { in successful } \\
\text { implementation of program }\end{array}$ & $\begin{array}{l}\text { Article primarily } \\
\text { regarding use of Logic } \\
\text { Model and not a research } \\
\text { article }\end{array}$ \\
\hline
\end{tabular}




\section{CHAPTER 3}

Nurse externship programs were initially developed by healthcare institutions as a recruitment tool for new nurses. Literature has reported the positive outcomes of the program on the participants but during times of economic difficulties, health care institutions discontinue the program. The studies demonstrating the financial impact of the program are limited to the recruitment phase and the 2 -year retention of the nurses. There is a need to demonstrate the longterm value of the program related to quality care indicators, retention, and return on investment (ROI).

Purpose. Nursing professional developers (NPDs) have learned the importance of utilizing return on investment (ROI) formulas to support the effectiveness of the various educational programs they develop, implement, evaluate, and maintain. Staff development programs constitute costs that include both labor and material expenses (Buerhaus, Auerbach, \& Staiger, 2009). As good stewards of their organizations, NPDs are expected to monitor the cost and outcomes of their educational programs. Established ROI formulas can assist NPDs in evaluating the outcomes of a program to hospital administrators whose perspective includes both $\mathrm{ROI}$ and quality patient outcomes. The purpose of this study is to develop a ROI formula that can be utilized to explain and justify the cost effectiveness of a nurse externship program in health care facilities.

Rationale for study. The Joint Commission (TJC) is an independent, not-for-profit organization that accredits and certifies more than 20,000 health care organizations and programs in the United States and worldwide (http://www.jointcommission.org). Joint Commission accreditation and certification are recognized internationally as a symbol of quality that reflects a healthcare organization's commitment to meeting certain performance standards. In an effort to 
provide evidence-based health care to the community, TJC in 1999 sought to develop sets of hospital core measures that when viewed together permitted a robust assessment of the care given in a focus area.

The Joint Commission collaborated with the Centers for Medicaid and Medical Services (CMS). It sought input from a variety of stakeholders and specialists in the development and roll out of the initial core measures. Core measures are evidence-based, scientifically researched standard of care that has been shown to result in improved clinical outcome (http://www.jointcommission.org). Appropriate core measure care reduces: (a) morbidity; (b) mortality; (c) complications; and (d) readmissions (Bielanski, 2009).

In 2003, five core measures were rolled out: (1) acute myocardial infarction; (2) congestive heart failure; (3) pneumonia; (4) surgical care improvement program; and (5) pregnancy related indicators (Bielanski, 2009). Since then core measures and indicators have been added and removed based on reported community needs and new scientific evidence. Hospitals with higher compliance with core measures receive a higher reimbursement from CMS (Stanley et al., 2008). The financial incentive coupled with the desire to provide evidence-based healthcare to the community prompted many health care organizations to introduce and hardwire core measures in their practice.

Since its original roll out in 2003 , the topic of core measures has been part of many training programs including: initial nursing orientation, unit-based orientation, new $\mathrm{RN}$ residency program, daily shift huddles, monthly staff meetings, annual nursing competency programs, and annual general hospital update programs. Although the majority of the staff members follow the core measures, there are a few staff members who do not consistently provide the care expected of them. The names of these staff members are included in the fall-out reports prepared by 
performance improvement specialists and will be used as an indicator of quality patient care. A list of reported core measures are shown in Appendix A.

In the ever-changing economics of healthcare NPDs have learned the importance of utilizing ROI formulas to support the value of the various programs they develop, implement, evaluate, and maintain (Buerhaus, Auerbach, \& Staige 2009). Staff development programs constitute costs that include both labor and material expenses. As good stewards of their organizations, NPDs are expected to monitor the cost and benefits of their programs. Established ROI formulas can assist NPDs in explaining the value of a program to hospital administrators who views both patient outcomes and ROI.

Healthcare expenditures are predicted to increase in the next two decades while hospital reimbursement is expected to decline unless healthcare providers meet quality measures (Centers for Medicare \& Medicaid Services, n.d.). Demonstrating the value of expenditures in terms that resonate with all stakeholders has increasingly become imperative (Makary, 2012). Changes in payment methods from a fee for service i.e., utilization, to a more quality-centered, pay-forperformance product will reward providers who demonstrate improvement in quality and efficiency (Flower, 2013). Centers for Medicare and Medicaid Services (CMS) and other paying entities will soon award contracts and favorable revenue arrangements to providers that demonstrate value through outcomes. Healthcare systems are now working toward building internal systems that not only deliver better outcomes but also prove them. Efforts are thus needed to convert the impact of projects into data that demonstrates the organization's return on investment (ROI).

\section{Study Aims.}

Aim 1. Determine the relationships between nursing student externship, 

a. extension of new graduate, unit-based orientation and
b. working full time over the first 5 years of employment.

Aim 2. Determine the relationship between nurse externship and adherence to select quality care indicators:
a. Acute myocardial infarction (AMI)
b. Heart failure (HF)
c. Pneumonia
d. Surgical Care Improvement Project (SCIP)
e. Outpatient Department
f. Emergency Department
g. Immunization
h. Stroke
i. Venous Thrombosis

Aim 3. Develop a ROI formula that can be utilized to explain the cost effectiveness of a nurse externship program.

\section{Research questions.}

Question 1. What is the relationship between student nurse externship experience and extension of the new graduate, unit-based orientation?

Question 2. What is the relationship between student nurse externship experience and working full time over the first 5 years of employment?

Question 3. What is the relationship between nurse externship experience and select patient care quality indicators? 
Setting. The setting of this study was a 625-bed, multi-hospital system in the East San Gabriel Valley of Los Angeles County. The system includes a free standing hospice and 3 acute care campuses in the cities of Covina, West Covina, and Glendora, California. There are 3,100 employees and 1,000 physicians with privileges who work within the system. The system is the largest employer of health care professionals in the East San Gabriel Valley of Los Angeles county and works collaboratively with nursing schools within the valley to provide clinical rotation and externship experience to nursing students.

Sample. The purposive study sample included 170 new graduate RNs hired from January 2005 to December 2008 at the 3 acute care facilities or campuses of the multi-hospital system. The facilities are identified as Campus 10, Campus 11, and Campus 12. Although the RNs were hired into the various campuses, they are all employees of the single, corporate healthcare system. They were hired into the nursing departments where new graduate nurses are most frequently employed. The nursing departments are listed in Table 1. The nursing departments not included in this sample include the surgical services, transitional, psychiatric units. The time frame allows measurement of the 5-year outcomes of the program and exclude the former externs who were hired as new RNs before the inauguration of the organization's Mentorship and Professional Program (MAP Program) in 2005. All newly graduates nurses are required to attend the 12-weeek MAP Program in its entirety. The MAP Program is composed of a cultural competency program, enhanced preceptor workshop, RN Residency Program, and unit-based orientation. A growing body of literature has demonstrated the positive outcomes of RN residency programs (Beecroft, Kunzman, \& Krozek, 2001; Ulrich et al., 2010; Rush, Adamack, Gordon, Lilly, \& Janke, 2013). Thus the timeframe for the study was adjusted to ensure all the participants of the study consistently received the benefits of the residency program. The RN 
participants were divided into two groups for correlational study: those who participated in nurse externship program and those who did not.

Table 2.

List of cost centers and nursing departments where the majority of the newly graduate nurses are hired.

\begin{tabular}{cc}
\hline Expense Cost Center \& Campus & Cost Center Name \\
\hline 10.60110 & Surgical Intensive Care Unit \\
10.60350 & Coronary Care Unit \\
10.61510 & Definitive Observation Unit - South \\
10.61540 & Cardiovascular Definitive Observation Unit \\
10.61710 & Medical/Surgical 3rd Floor \\
10.61730 & Medical/Surgical 2nd Floor \\
10.70130 & Emergency Services \\
11.60120 & Intensive Care Unit \\
11.60350 & Coronary Care Unit \\
11.60710 & Neonatal Intensive Care Unit \\
11.61510 & Definitive Observation Unit \\
11.61520 & Definitive Observation Unit - North \\
11.61710 & Medical/Surgical Sth Floor \\
11.61730 & Medical/Surgical 4th Floor \\
11.63810 & Mother/Baby Care Unit \\
11.70130 & Emergency Services \\
11.74000 & Labor \& Delivery \\
12.60130 & Intensive Care Unit \\
12.61510 & Definitive Observation Unit \\
12.61740 & Medical/Surgical Floor \\
12.69990 & Diabetes Care Unit - 4th Floor \\
12.70130 & Emergency Services \\
12.74000 & Labor \& Delivery \\
\hline
\end{tabular}

Note. Prefixes 10,11,12 denote the 3 acute care facilities within the system

Operational definitions. The following definitions of terms provided the context in which they are used within the study.

Core measures. Evidence-based, scientifically researched standard of care that has been shown to result in improved clinical outcome (http://www.jointcommission.org). Appropriate 
core measure care reduces: (a) morbidity; (b) mortality; (c) complications; and (d) readmissions (Bielanski, 2009).

Impact data. Data that demonstrate the amount of change directly attributable to a project. Some projects may be directly related to a change in quality outcomes, patient, or employee satisfaction. For other projects, this may be sufficient (Phillips, Brantley, \& Phillips, 2011). For this study, it will be necessary to convert data to monetary values to measure the impact of the externship program.

Mentorship. A transmission process by which a mentor, or one who is perceived to be more knowledgeable, transfers relevant information, knowledge, social capital, and psychological support to a protégé or one who is perceived as less knowledgeable between the two (Bozeman \& Feeney, 2007). The knowledge transferred is relevant to work, career and professional growth. The informal process and naturally occurring relationship between the two provide emotional support especially during the challenging phase of transition.

Nurse externship program. Pre-licensure program that provides one on one learning experiences while nursing students are working closely with a $R N$ providing direct patient care in an acute care setting (Kilpatrick \& Frunchak, 2006). The nursing students are enrolled in a work-study program that provides college units for this experience. The externs are permitted to perform nursing interventions at the level of their most recently completed semester while under the direct supervision of a RN preceptor. In California, the Nursing Practice Act permits students to enroll as nursing student workers and hospitals are encouraged to compensate the students while they perform nursing functions within the hospital (www.m.ca.gov).

Preceptorship. Process designed to assist newly graduated nurses transition from the nursing role to the professional nurse role with the close guidance of a RN (Marks-Maran et al., 
2012). During this process, the preceptor assists the preceptee in the completion of specific unitbased competencies required for orientation to the unit. This process may also take place prior to licensure while the individual is a student in the final semester of a nursing program. Students in preceptorship are required to complete specific course objectives that lead to completion of a nursing course. In both cases, the preceptee is formally assigned to a preceptor employed in a specific patient care area. Preceptors are often chosen after completion of a formal preceptor training program and demonstration of clinical competence, effective communication and time management skills.

Return on investment. Program evaluation that measures the financial impact of education activities. Also referred to as a level five evaluation (Kirkpatrick, 1998). It involves critical steps of isolating the effects of the program and converting impact data to monetary values. The factors included in a ROI formula are selected by the institutions experts and stake holders. A common formula for calculating $\mathrm{ROI}$ is: $\mathrm{ROI}(\%)=$ net program benefits/net program cost $x 100$ (Beecroft, Kunzman, \& Krozek, 2001). A result greater than one is considered profitable. The ROI also includes identifying intangible benefits valued by stakeholders of the organization.

RN Residency Program. Also referred to as new nurse transition programs (NNTPs) or nurse residencies in hospitals across the United States (Hoffart et al., 2011). The goals of the program are to facilitate the transition between pre-licensure educational programs and professional nursing practice and to retain them in the nursing workforce (Beecroft et al., 2001). The program includes classroom activities, unit-based preceptorship, mentorship, and debriefing. 
Data collection instruments/measures. Investigator developed data collection tool as shown in Appendix B was used to derive information from the organization's human resources and payroll departments. The variables, source, responses, and codes are shown in Table 3.

Table 3.

Table of variables, department source of information, responses, and code.

\begin{tabular}{|c|c|c|c|}
\hline Variables & Source & Responses & Code \\
\hline Employee Number & HR & Six digit employee number & N/A \\
\hline \multirow[t]{2}{*}{ Gender } & HR & Male & 0 \\
\hline & & Female & 1 \\
\hline Age & HR & Number & N/A \\
\hline Number of hours worked as extern & Payroll & Number & N/A \\
\hline $\begin{array}{l}\text { Cost center of department employed } \\
\text { at as new grad }\end{array}$ & Payroll & Number & N/A \\
\hline $\begin{array}{l}\text { Number of hours in orientation as } \\
\text { new grad }\end{array}$ & Payroll & Number & N/A \\
\hline $\begin{array}{l}\text { Number of hours during first } 5 \text { years } \\
\text { of employment }\end{array}$ & Payroll & Number & N/A \\
\hline
\end{tabular}

Data collection, management and analysis. The data were collected solely by the primary investigator (PI) using the data collection tool as shown in Appendix B. The electronic data were stored on a laptop with two access codes. The access codes are listed in the primary investigator's personal digital assistant device that also requires an access code. Both access codes are committed to the memory of the primary investigator. All hardcopy data are stored in a locked drawer that can be opened by only 1 key. Only the primary investigator has possession of the key.

Study participants. Internal Review Board (IRB) approval was obtained from both the University of San Diego and the participating facilities prior to the commencement of the study. Extension of unit-based new graduate orientation. The Payroll Department's data bank does not include specific information as to whether or not a new graduate nurse extended unit- 
based orientation. Each patient care area has its own expected length of time for orientation to the area that is based on previous years experience. Furthermore, there are also variations amongst campuses in the length of time of orientation for similar patient care areas, e.g., at campus 12 , the length of orientation for new graduate RNs employed in the emergency department is 24 weeks while at campus 11 the length of orientation is 12 weeks. To determine whether a new graduate $\mathrm{RN}$ extended orientation Table 3 were used as a reference. The PI reviewed the orientation hours of each new graduate and compared them to the length of new graduate orientation per patient care area to discern whether or not they extended their unitspecific orientation.

Table 4.

Table of length of new graduate nurse orientation per patient care area

\begin{tabular}{llll}
\hline \multicolumn{1}{c}{ Patient Care Area } & \multicolumn{1}{c}{ Campus 10 } & Campus 11 & Campus12 \\
\hline Diabetes Care Unit & N/A & & 12 weeks \\
\hline Medical Surgical & 6 weeks & 10 weeks & 12 weeks \\
Definitive Observation Unit & 12 weeks & 12 weeks & 12 weeks \\
Intensive Care Unit & 12 weeks & 12 weeks & 24 weeks \\
Emergency Department & 12 weeks & 12 weeks & 24 weeks \\
Neonatal Intensive Care Unit & N/A & 12 weeks & N/A \\
Labor and Delivery & N/A & 8 weeks & 24 weeks \\
Mother Baby Care Unit & N/A & 8 weeks & N/A \\
\hline
\end{tabular}

Note. Prefixes $10,11,12$ denote the 3 acute care facilities within the system. Specialties in each of the campus are based on the community and population needs. Unavailability of the specialty in a particular facility is indicated by "N/A".

Full-time hours worked during first 5 years of employment. Although new graduate nurse orientation varies from campus to campus, training expenses are always a concern. Fiveyear retention of full-time employment at the facility denotes a return on the training investment. New graduate clinical nurses are employed on 12-hour shifts. Full time employment requires 3 12-hour shifts a week or 6 12-hour shifts in a 2-week pay period for a total of 72 hours per pay period. There are 26 pay periods in a year. Thus full time employment for a 12-hour employee is 
equal to 72 hours multiplied by 26 weeks or 1872 hours a year. Over a 5 -year period, the total hours of full time employment is 9360 hours. Full time employment will include regular hours, paid time off, leave of absences, and education hours. Given the fact that this population is comprised of a majority of women in childbearing age, maternity leave occurrence will not affect the employee's employment status i.e., they will still retain their current status for the purposes of this study.

Statistical analysis. Descriptive statistics were used to describe the data set including mean, mode, and median analysis. Inferential statistics will be used to infer the results based on a sample to a population using the $t$-test for continuous data and chi-square for categorical data. Correlational statistics will be used to analyze the correlation of the independent variable, nurse externship experience and dependent variables: (a) extension of unit based orientation; (b) full time hours during first 5 years of employment; and (c) inclusion in fall-out report, using phi coefficient or mean square contingency coefficient. The measurements were chosen because the variables are both categorical and dichotomous as shown in Tables 4,5 , and 6 . The tables serve as a visual guide to the research questions. Once the data of the two groups are obtained and compared, the difference between the data will then be utilized in the ROI formula.

Table 5 .

Contingency table for extension of unit based orientation

\begin{tabular}{llccc}
\hline & & \multicolumn{2}{c}{ Extension of unit based orientation } & Total \\
\hline Externship & Yes & Yes & No & \\
Experience & No & & & \\
Totals & & & & \\
\hline
\end{tabular}


Table 6.

Contingency table for first 5 years of employment

\begin{tabular}{llcll}
\hline & & $\begin{array}{c}\text { Full time hours during first 5 years of } \\
\text { employment }\end{array}$ & Total \\
\hline $\begin{array}{l}\text { Externship } \\
\begin{array}{l}\text { Experience } \\
\text { Totals }\end{array}\end{array}$ & Yes & Yes & No & \\
\hline
\end{tabular}

Table 7.

Contingency table for core measures fall out report

\begin{tabular}{lcccc}
\hline & & RN included in core measures fall out report & Total \\
\hline Externship & Yes & Yes & No & \\
$\begin{array}{l}\text { Experience } \\
\text { Totals }\end{array}$ & No & & & \\
\hline
\end{tabular}

The financial component of the ROI as shown in Table 8 includes the cost i.e., salary of externs, benefits, preceptor differential, and on-boarding expenses; and benefits i.e., 5-year retention, savings from not extending unit-based new RN orientation, and patient quality indicators. The intangible component of the ROI includes the cost i.e., time of administration by both the hospital and school; and benefits, i.e., extern familiarity to the facility, mentorship for the nurse extern, ease of transition as a new RN, extern and preceptor satisfaction. The intangible component of the program was not within the scope of this study. The preliminary ROI formula is: net program benefits divided by cost multiplied by 100 . The ROI is reported as a percentage. 
Table 8.

List of financial factors in the ROI formula

\begin{tabular}{ccc}
\hline & Financial & \\
\hline Cost & Benefit \\
\hline Salary of externs & 5-year retention
\end{tabular}

Employment benefits

Non-extension of new RN unit based orientation

Preceptor differential

Quality care savings

On-boarding expenses

Note. ROI formula includes both financial and intangible costs and benefits of the program.

Table 9.

List of intangible factors in the ROI formula

\begin{tabular}{cc}
\hline & Intangible \\
\hline Cost & Benefit \\
\hline $\begin{array}{c}\text { Time spent in project } \\
\text { administration by } \\
\text { hospital } \\
\begin{array}{c}\text { Time spent in project } \\
\text { administration by } \\
\text { school }\end{array}\end{array}$ & $\begin{array}{c}\text { Extern familiarity to } \\
\text { facility }\end{array}$ \\
& Mentorship for extern \\
& Ease of transition as a new \\
& RN \\
& Extern satisfaction \\
& Preceptor satisfaction \\
\hline
\end{tabular}

Note. ROI formula includes both financial and intangible costs and benefits of the program.

Summary. Nursing professional developers (NPDs) have learned the importance of utilizing return $\mathrm{ROI}$ formulas to explain the effectiveness of the various educational programs. Staff development programs constitute costs (Buerhaus, Auerbach, \& Staiger, 2009). As good stewards of their organizations, NPDs are expected to monitor the cost and outcomes of their educational programs. Established ROI formulas can assist NPDs in evaluating the outcomes of 
a program to hospital administrators whose perspective includes both $\mathrm{ROI}$ and quality patient outcomes. The statistical analysis included in this project will lend itself to the development of an ROI that can be utilized to explain and justify the cost effectiveness of a nurse externship program in health care facilities. 


\section{CHAPTER 4}

This chapter provides a detailed analysis of research findings comparing the nurses with externship experience to nurses without externship experience. A summary of the participant demographic and descriptive data is presented in detail. The results of the study findings are organized around each of the following research aims:

Aim 1. Determine the relationships between nursing student externship,

a. extension of new graduate, unit-based orientation and

b. working full time over the first 5 years of employment.

Aim 2. Determine the relationship between nurse externship and adherence to select quality care indicators including:
a. Acute myocardial infarction (AMI)
b. Heart failure (HF)
c. Pneumonia
d. Surgical Care Improvement Project (SCIP)
e. Outpatient Department
f. Emergency Department
g. Immunization
h. Stroke
i. Venous Thrombosis

Aim 3. Identify new study findings that can be used to develop a ROI formula to explain the cost effectiveness of a nurse externship program. The newly developed ROI formula will be discussed in detail in Chapter 5. 
Sample description. The purposive study sample included 123 newly graduate RNs hired from January 2005 to December 2008 at the 3 acute care facilities or campuses of a multihospital system located in the East San Gabriel Valley of Los Angeles County in California. All of the study participants received the benefit of participating in the facility's Mentorship and Professional Development (MAP) Program during which they were assigned a mentor to ease their transition into their role as a licensed professional in addition to their unit-based preceptor. Newly graduate RNs who were terminated before the end of their MAP Program were excluded from the sample.

The study participants were initially employed in patient care areas that are known to historically and consistently hire newly graduate nurses. The areas are adept to hiring and precepting newly graduate nurses such as the adult medical/surgical floors, telemetry, and emergency departments. See Table 10 below for the number of newly graduate nurses hircd in the various patient care areas across the enterprise. Each of the 3 hospitals has different patient care areas and specialties based on the needs of its immediate population and community. Table 11 contains the number of newly graduate nurses hired in each of the combined specialty areas within the enterprise.

Table 10.

Patient care areas where the new grad RNs were initially hired

\begin{tabular}{lccc}
\hline \multicolumn{1}{c}{ Initial Hiring Unit } & Non-Externs & Externs & New Grad RNs \\
\hline $10 \mathrm{CCU}$ & 1 & 1 & 2 \\
$10 \mathrm{ED}$ & 3 & 2 & 5 \\
10 3rd Floor M/S & 1 & 1 & 2 \\
$10 \mathrm{DOU}$ & 17 & 2 & 19 \\
10 2nd Floor M/S & 14 & 0 & 14 \\
11 5th Floor M/S & 10 & 1 & 11 \\
11 4th Floor M/S & 6 & 1 & 7 \\
11 3rd Floor DOU & 5 & 8 & 13 \\
$11 \mathrm{~L} \& D$ & 6 & 0 & 6 \\
$11 \mathrm{ED}$ & 6 & 0 & 6
\end{tabular}




\begin{tabular}{lccc}
$11 \mathrm{NICU}$ & 11 & 0 & 11 \\
$11 \mathrm{MBCU}$ & 9 & 0 & 9 \\
$11 \mathrm{ICU}$ & 1 & 0 & 1 \\
$12 \mathrm{Med} /$ Surg/DCU & 3 & 1 & 4 \\
$12 \mathrm{DOU}$ & 4 & 0 & 4 \\
$12 \mathrm{ICU}$ & 2 & 1 & 3 \\
$12 \mathrm{ED} \quad$ Total & 4 & 2 & 6 \\
& 103 & 20 & 123 \\
\hline
\end{tabular}

Note. Prefixes 10,11,12 denote the 3 acute care facilities within the system. Specialties in each of the campus are based on the community and population needs.

Table 11.

Summary of specialty areas from within the enterprise where new grad RNs were hired

\begin{tabular}{lccc}
\hline \multicolumn{1}{c}{ Specialty Areas } & Non-Externs & Externs & New Grad RNs \\
\hline Adult ICU/CCU & 4 & 2 & 6 \\
DOU/Telemetry & 28 & 10 & 38 \\
Emergency Department & 11 & 4 & 15 \\
Adult Medical/Surgical & 34 & 4 & 38 \\
Neonatal ICU & 11 & 0 & 11 \\
Labor \& Delivery & 6 & 0 & 6 \\
Mother Baby Care Unit & 9 & 0 & 9 \\
Total & 103 & 20 & 123 \\
\hline
\end{tabular}

The unit-based preceptors assigned to the newly graduate nurses were required to complete a preceptor workshop prior to their accruing preceptor differential. The few RNs hired into other specialty areas such as pediatrics, the surgical intensive care units, transitional care unit, float pool, perioperative, and mental health departments were excluded from the study since externs are not usually assigned to the units and newly graduate nurses are seldom hired into these particular units.

The sample, as seen in Table 12, of 123 newly graduate RNs was composed of $20 \mathrm{RNs}$ with externship experience and 103 with no externship experience. The sample included 32 males comprising $26 \%$ of the sample and 91 females comprising $74 \%$ of the sample. The median age of the newly graduate $\mathrm{RN}$ participants was 38 years, with a mean of 39 years. The sample 
included 73 or $59 \%$ Asians, 4 or 3.3\% Black Americans, 21 or $17 \%$ Hispanic/Latinos, and 25 or $20 \%$ Whites Americans.

Table 12.

Demographic information of sample

\begin{tabular}{lccc}
\hline & & Externship Experience & No Externship Experience \\
\hline Total & 123 & $20(16 \%)$ & $103(84 \%)$ \\
Gender & & & \\
Male & $32(26 \%)$ & $5(25 \%)$ & $27(26.2 \%)$ \\
Female & $91(74 \%)$ & $15(75 \%)$ & $76(73.8 \%)$ \\
Age & & & \\
Median & 38 & 34 & 38 \\
Mean & 39 & 37 & 40 \\
Race & & & \\
Asian & $73(59 \%)$ & $11(55 \%)$ & $62(60 \%)$ \\
Black American & $4(3.3 \%)$ & $1(5 \%)$ & $3(2.9 \%)$ \\
Hispanic/Latino & $21(17 \%)$ & $4(20 \%)$ & $17(16.5 \%)$ \\
White & $25(20 \%)$ & $4(20 \%)$ & $21(21 \%)$ \\
\hline
\end{tabular}

\section{Aim 1a. Determine the relationships between nursing student externship and} extension of new graduate, unit-based orientation. Chi-square statistic and phi coefficient analysis were utilized to determine the relation between externship experience and extension of the new graduate, unit-based orientation. A negative relationship was found between 20 newly graduate nurses with externship experience and 103 newly graduates nurses without externship experience and extension of unit based orientation, $X^{2}(1)=4.8, p<.05$.

Table 13.

Contingency table for extension of unit based orientation

\begin{tabular}{llccc}
\hline & & \multicolumn{2}{c}{ Extension of unit based orientation } & Total \\
\hline & & Yes & No & \\
Externship & Yes & $8(11 \%)$ & $12(26 \%)$ & $20(16 \%)$ \\
Experience & No & $68(89 \%)$ & $35(74 \%)$ & $103(84 \%)$ \\
Totals & & $76(100 \%)$ & $47(100 \%)$ & $123(100 \%)$ \\
\hline
\end{tabular}


Table 14.

Chi square tests for extension of unit based orientation

\begin{tabular}{lccc}
\hline & Value & df & Asymp. Sig. (2-sided) \\
\hline Pearson Chi-Square & 4.802 & 1 & 0.028 \\
Likelihood Ratio & 4.665 & 1 & 0.031 \\
Linear-by-Linear Association & 4.763 & 1 & 0.029 \\
\hline N of Valid Cases & 123 & & \\
\hline
\end{tabular}

Table 15.

Symmetrical measures for extension of unit based orientation

\begin{tabular}{llcc}
\hline & & Value & Approx. Sig \\
\hline Nominal by Nominal & Phi & -0.198 & 0.028 \\
& Cramer's V & 0.198 & 0.028 \\
N of Valid Cases & & 123 & \\
\hline
\end{tabular}

\section{Aim 1b. Determine the relationships between nursing student externship and} working full time over the first 5 years of employment. Chi-square statistic and phi coefficient analysis were utilized to determine the relation between nurse externship experience and working full time at the organization over the first years of employment. No statistically significant relationship was found between the 20 newly graduate nurses with externship experience and 103 RNs with no externship experience and full time hours worked during the first 5 years of employment, $X^{2}(1)=.03, p>.05$.

Table 16.

Contingency table for full time hours worked during first 5 years of employment

\begin{tabular}{lcccc}
\hline & \multicolumn{4}{c}{ Full time hours during first 5 years of } \\
employment & Total \\
\hline & & Yes & No & \\
Externship & Yes & $7(17 \%)$ & $13(16 \%)$ & $20(16 \%)$ \\
Experience & No & $34(83 \%)$ & $69(84 \%)$ & $103(84 \%)$ \\
Totals & & $41(100 \%)$ & $82(100 \%)$ & $123(100 \%)$ \\
\hline
\end{tabular}


Table 17.

Chi-square tests for full time hours worked during first 5 years of employment

\begin{tabular}{lccc}
\hline & Value & df & Asymp. Sig. (2-sided) \\
\hline Pearson Chi-Square & 0.03 & 1 & 0.863 \\
Likelihood Ratio & 0.03 & 1 & 0.863 \\
Linear-by-Linear Association & 0.3 & 1 & 0.863 \\
\hline N of Valid Cases & 123 & & \\
\hline
\end{tabular}

Table 18.

Symmetrical measures for full time hours worked during first 5 years of employment

\begin{tabular}{llcc}
\hline & & Value & Approx. Sig \\
\hline Nominal by Nominal & Phi & 0.016 & 0.863 \\
N of Valid Cases & Cramer's V & 0.016 & 0.863 \\
& & 123 & \\
\hline
\end{tabular}

Aim 2. Determine the relationship between nurse externship and adherence to select quality care indicators:
a. Acute myocardial infarction (AMI)
b. Heart failure (HF)
c. Pneumonia
d. Surgical Care Improvement Project (SCIP)
e. Outpatient Department
f. Emergency Department
g. Immunization
h. Stroke

i. Venous Thrombosis

Chi-square statistic and phi coefficient analysis were utilized to determine the relation between externship experience and adherence to select quality care indicators. Fall out reports 
were reviewed from the start of its inception at the facility at the first quarter of 2010 till the third quarter of 2013. No statistical relationship was found between newly graduate nurses with externship experience and those with no externship experience and adherence to select quality indicators, $X^{2}(1)=.62, p>.05$.

Table 19.

Examples of details included in the patient care quality indicators and core measurements Acute Myocardial Infarction

Aspirin at arrival

Aspirin prescribed at discharge

ACEI or ARB for LVSD

Beta blocker prescribed at discharge

Fibrinolytic therapy within 30 minutes

PCI within 90 Minutes

Statin prescribed at discharge

PERECT CARE- AMI

Pneumonia

Blood cultures performed w/in 24 hours - ICU admits

Blood culture in emergency department before first antibiotic

Initial antibiotic selection for community acquired pneumonia in immunocompetent patient Initial antibiotic selection for community acquired pneumonia in Immunocompetent - ICU pt Initial antibiotic selection for community acquired immunocompetent - Non ICU patient PERFECT CARE- PNE

Heart Failure

Discharge instructions

Evaluation of left ventricular systole function

ACEI or ARB for LVSD

Adult smoking cessation advice/counseling

PERFECT CARE- HF 
Table 20.

Contingency table for core measures fall out report

\begin{tabular}{lcccc}
\hline & \multicolumn{3}{c}{ RN included in core measures fall out report } & Total \\
\hline & & Yes & No & \\
Externship & Yes & $5(22 \%)$ & $15(15 \%)$ & $20(16 \%)$ \\
Experience & No & $18(78 \%)$ & $85(85 \%)$ & $103(84 \%)$ \\
Totals & & $23(100 \%)$ & $100(100 \%)$ & $123(100 \%)$ \\
\hline
\end{tabular}

Table 21.

Chi-square tests for inclusion in core measures fall out report

\begin{tabular}{lccc}
\hline & Value & df & Asymp. Sig. (2-sided) \\
\hline Pearson Chi-Square & 0.624 & 1 & 0.43 \\
Likelihood Ratio & 0.587 & 1 & 0.444 \\
Linear-by-Linear Association & 0.619 & 1 & 0.432 \\
\hline N of Valid Cases & 123 & & \\
\hline
\end{tabular}

Table 22 .

Symmetrical measures for inclusion in core measures fall out report

\begin{tabular}{llcc} 
& & Value & Approx. Sig \\
\hline Nominal by Nominal & Phi & 0.071 & 0.43 \\
N of Valid Cases & Cramer's V & 0.071 & 0.43 \\
\hline
\end{tabular}

\section{Aim 3. Develop a ROI formula that can be utilized to explain the cost effectiveness}

\section{of a nurse externship program.}

The findings demonstrated immediate impact of the externship program during the initial employment phase of a new registered nurse. The variable demonstrating a positive impact is the extension of unit-based orientation i.e., compared to newly graduate RNs with no extern experience, former externs extend their unit-based orientation less. The average number of hours of extended orientation is 100 hours for both cohorts of participants. The study has two key findings i.e., less extension of unit-based orientation and the average of 100 hours of unit-based 
orientation extension, that can not only be added to the existing body of literature but can also be used as factors in the ROI formula for externship programs.

The externship experience showed no statistical relationship to the long-term variables chosen for the study i.e., working full-time hours over the first 5 years of employment and adherence to core measures.

Conclusion. In the sample of newly graduate RNs, RNs with externship experience extended their unit-based orientation less than those with no externship experience. The average number of hours of orientation extension for both cohorts is 100 hours. This number is magnified by the larger number of non-externs extending orientation than the externs. There were no statistical differences between the two groups in relation to working full time over the first 5 years of employment and adherence to select core measures. The two new findings can now be used in developing a ROI formula for externship. 


\section{CHAPTER 5}

Nurse externship programs were initially developed by healthcare institutions as a recruitment tool for new nurses. Literature has demonstrated the positive outcomes of the program on the participants (Lott et al., 2011; Ruth-Sahd et al., 2010; Kilpatrick \& Frunchak, 2006; Cantrell \& Browne, 2005) but during times of economic difficulties, health care institutions discontinue the program. Historical time periods of national economic difficulties have been found to correlate with high $\mathrm{RN}$ retention rates in acute care facilities (Buerhaus et al., 2009) thus healthcare institutions justify the discontinuation of the program during times of economic downturns. The studies demonstrating the financial impact of the program are limited to the recruitment phase and the 2-year retention of the nurses (Pine \& Tart, 2007; Cantrell \& Browne, 2006). There is thus a need to add to the existing literature on nurse externship programs by demonstrating the long-term value of the program related to quality care indicators, retention, and return on investment (ROI).

This chapter provides a detailed analysis and discussion of research findings comparing the nurses with externship experience to nurses without externship experience. The findings ware to be used to develop a ROI formula based on the ROI Methodology ${ }^{\mathrm{TM}}$ Model developed by J.J. Phillips (Phillips, 2007). The discussion about the project ROI will address the two foci of this study i.e., Level 4 or project impact and Level 5 the project ROI, the last two steps in the ROI Methodology measurement and evaluation phase as seen in Figures 2 and 3. Implications of the study findings in relation to academia, practice, research, and administration will be presented. 


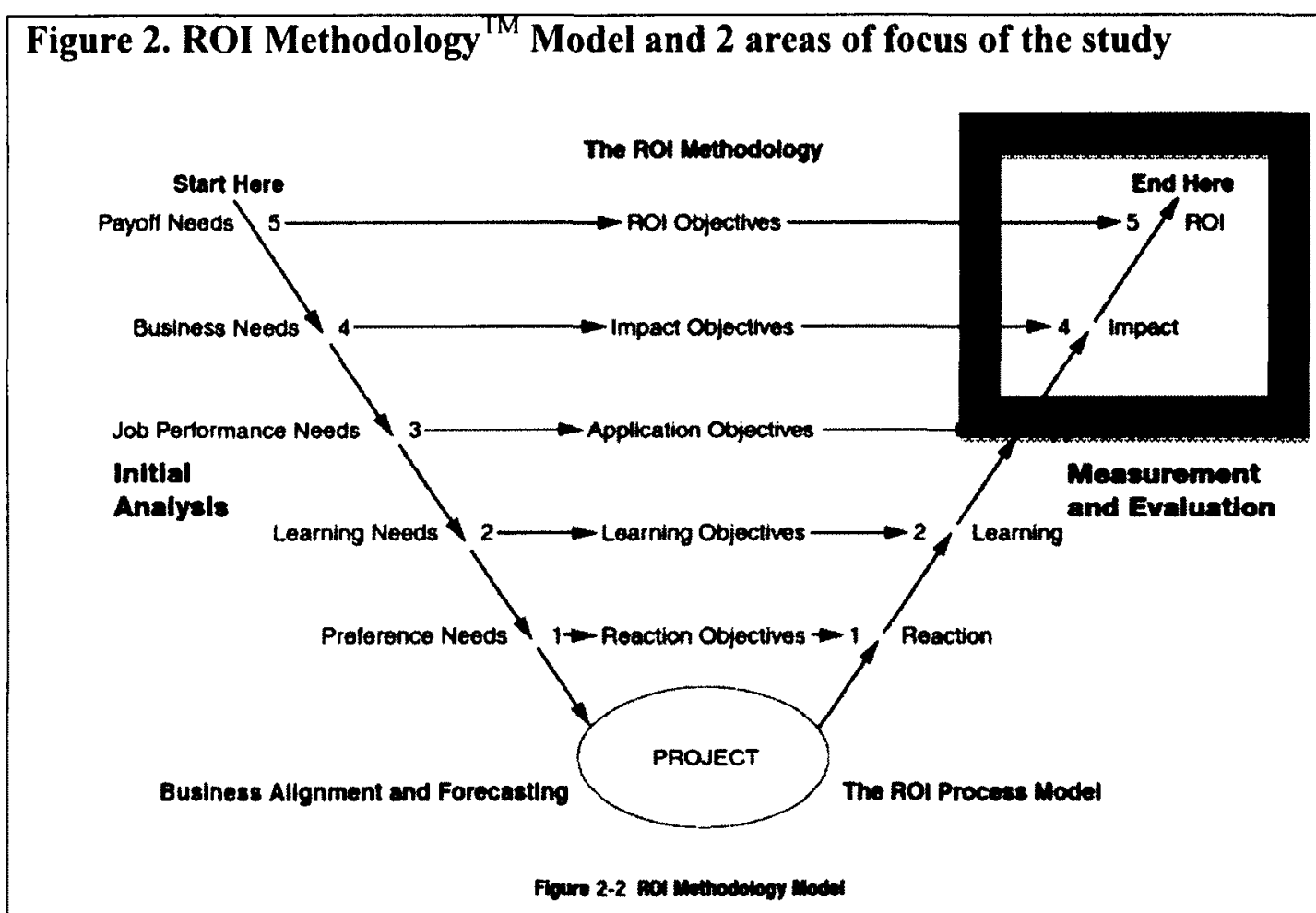

Figure 2. The two areas of focus of the research project include levels include the impact or level 4 and ROI or level 5 of the measurement and evaluation phase of the ROI process model.

The sample of 123 newly graduate RNs was composed of 20 RNs with externship experience and 103 with no externship experience. As expected, only a small portion of the total sample RNs had externship experience because of the limited number of positions available. The median age of the newly graduate $\mathrm{RN}$ participants in the sample was 38 and the mean age was 39,8 younger than the California average age of RNs currently in the workforce of 47 in 2008 . The sample had a larger percentage of males than both the existing RN population in the facility and the California RN percentage that was reported by Bates and Dower (2010). The percentage is reflective of the increasing number of male RNs admitted to the schools in the recent years.

The percentage of Asians in the sample is far larger than the California RN percentage reported by Bates and Dower (2010) while the percentage of White Americans is far less but the 
two figures are reflective of the facility's existing RN population. The percentage of Hispanic/Latinos in this sample is higher than the facility's at the time and is reflective of the efforts of the organization to develop a workforce that mirrors the ethnic diversity of the population it serves. The facility is located in and thus serves the East San Gabriel Valley of Los Angeles, an area heavily populated by Hispanic/Latinos.

A negative relationship was found between 20 newly graduate nurses with externship experience and 103 newly graduates nurses without externship experience and extension of unit based orientation, $X^{2}(1)=4.8, p<.05$. Newly graduate nurses with externship experience extended their unit-based orientation less than those without externship experience. This is a new finding not found in the existing nurse externship literature that focus on the recruitment effects of the program. Upon closer examination, the newly graduate nurses who extended their unit based orientation did so by an average of 100 hours. The cost of the orientation extension is magnified by the large number of nurses hired with no externship experience. In the sample of 123 new grads, 103 or $84 \%$ did not have extern experience, of which 68 extended their new grad unit based orientation while 8 of the 20 former externs extended their orientation. The unit-based orientation cost to the organization for this sample can be reached by using this formula: number of new grads (extern or non-extern) extended their orientation multiplied by the new grad pay rate and 100 hours plus preceptor differential multiplied by 100 hours. 
Table 23

Cost of unit based orientation extension per newly graduate registered nurse

\begin{tabular}{lcc}
\hline & \multicolumn{2}{c}{ Newly Graduate Registered Nurse } \\
\cline { 2 - 3 } & $\begin{array}{c}\text { With Nurse Externship } \\
\text { Experience }\end{array}$ & $\begin{array}{c}\text { With No Nurse Externship } \\
\text { Experience }\end{array}$ \\
\hline Pre-licensure & & \\
\hline $\begin{array}{l}\text { Salary }= \\
\$ 14(12 \text {-hour rate) } * 300\end{array}$ & $\$ 4,200$ & \\
$\begin{array}{l}\text { Preceptor differential }= \\
\$ 1.20^{*} 300\end{array}$ & $\$ 360$ & \\
\hline Post-licensure & & $\$ 3,400$ \\
\hline $\begin{array}{l}\text { Extension of Orientation= } \\
\$ 34 * 100\end{array}$ & $\$ 3,400$ & $\$ 120$ \\
Preceptor differential $=$ & $\$ 120$ & $\$ 3,520$ \\
$\$ 1.20 * 100$ & $\$ 8,080$ & \\
\hline Total cost & & \\
\hline
\end{tabular}

Table 24

Factors included in the formula to determine the cost of unit-based orientation extension of the study sample

\begin{tabular}{ccc}
\hline Description of factors included in formula \\
$\begin{array}{c}\text { Number of new grads with } \\
\text { extern experience }(\mathrm{N})\end{array}$ & $\begin{array}{c}\text { Multiplied } \\
\text { by }\end{array}$ & $\begin{array}{c}\text { Sum of the average new grad pay rate from 2005- } \\
2013(\$ 34) \text { and multiplied by the average hours of } \\
\text { extension }(100) \text { plus the preceptor differential }(\$ 1.20) \\
\text { multiplied by the average hours of extension }(100)\end{array}$ \\
$\begin{array}{c}\text { Number of new grads with } \\
\text { no extern experience }(\mathrm{N})\end{array}$ & & \\
\hline Factors included in formula & $\mathrm{X}$ & $(\$ 34 * 100)+(\$ 1.20 * 100)$ \\
\hline $\mathrm{N}$ & &
\end{tabular}

Formula for expense of the extension of unit-based orientation of new grads with extern experience: Number of new grads with extern experience (8) multiplied by the sum of the average new grad pay rate from 2005-2013 (\$34) multiplied by the average hours of extension (100) plus the preceptor differential (\$1.20) multiplied by the average hours of extension (100) 


$$
\begin{aligned}
& =8 *[(\$ 34 * 100)+(\$ 1.20 * 100)] \\
& =8 *(\$ 3,400+\$ 120) \\
& =8 * \$ 3,520 \\
& =\$ 28,160
\end{aligned}
$$

Formula for expense of extension of unit-based orientation of new grads with no extern experience: Number of new grads with no extern experience (68) multiplied by the sum of the average new grad pay rate from 2005-2013 (\$34) multiplied by average hours of extension (100) plus the preceptor differential (\$1.20) multiplied by the average hours of extension (100)

$$
\begin{aligned}
& =68[\$ 34 * 100)+(\$ 1.20 * 100)] \\
& =68 *(\$ 3400+\$ 120) \\
& =68 * \$ 3,520 \\
& =\$ 239,360
\end{aligned}
$$

No relationship was found between the 20 newly graduate nurses with externship experience and 103 RNs with no externship experience and full time hours worked during the first 5 years of employment, $X^{2}(1)=.03, p>.05$. The two cohorts of participants had similar turnover practices over the first 5 years of employment. Earlier studies regarding RN retention of former nurse externs were limited to the first year (Cantrell \& Browne, 2006) or recruitment (Lott et al., 2011) of a former extern into a new RN position. This is the first 5-year study focused on the long-term $\mathrm{RN}$ retention results of the program.

No statistically significant relationship was found between newly graduate nurses with externship experience and those with no externship experience and adherence to select quality 
indicators, $X^{2}(1)=.62, p>.05$. The two cohorts had similar tendency to adhere to the quality indicators. The existing nurse extern studies focus on the immediate acquisition and application of knowledge (Kilpatrick \& Frunchak, 2006) and critical thinking (Lott et al., 2011). This is the first 5-year study focused on the adherence to quality indicators.

Upon further review of existing data, it became evident the inclusion in the fall out reports was also affected by the type of patient care area at which the new RNs were employed. Some areas included in the study did not require any core measurements, e.g., perinatal areas. The new nurses hired into such areas were not likely to have been cited in the fall out reports such as the acute myocardial infarction (AMI) measure.

Examples of fall out indicators included in the AMI measure are discharge prescriptions for beta blockers and statin drugs. Table 19 lists examples of details included in three of the quality indicators used in the project. Although many of the indicators are physician initiated, the RNs are responsible for coordinating the card of the patient and is thus cited in the fall out reports when the measures are not appropriately address in the documentation.

In addition to the patient care area, inclusion in the fall out report was also affected by the newness of the indicators and measurement. As new indicators are implemented, staff training is required for the learning need. The less familiar the staff with the process, the more chances they may omit a particular indicator or measurement. Further more, the longer the RN is employed at the facility, the more chances they may be in the fall out report, e.g., the RNs employed for less than 2 years had only up to 2 years of possible inclusion in the report while RNs employed for 5 years will have more chances of inclusion in the report.

Similar to earlier studies (Cantrell \& Browne, 2006; Lott et al., 2011; Pine \& Tart, 2007) this study showed immediate impact of the externship program during the initial employment 
phase of a new registered nurse. In this particular study, the variable demonstrating a positive impact is the extension of unit-based orientation i.e., compared to newly graduate RNs with no extern experience, former externs extend their unit-based orientation less. The average number of hours of extended orientation is 100 hours for both cohorts of participants. The externship experience showed no statistical correlations to the long-term variables chosen for the study i.e., working full-time hours over the first 5 years of employment and adherence to core measures. This information has not been reported in earlier studies and thus can be added to the existing body of knowledge regarding the short-term impact of the nurse externship program.

The program cost for this particular sample of externs includes salary of externs $(\$ 4,200)$ and preceptor differential $(\$ 300)$ multiplied by 20 externs is equal to $\$ 90,000$. The cost of the extension of their unit-based orientation for 8 of the externs is equal $\$ 28,160$. Added together, $\$ 90,000$ plus $\$ 28,160$ equal $\$ 118,160$. On the other hand, the cost of the orientation extension of the 68 RNs with no externship in the study sample is $\$ 239,360$ leaving a cost savings of $\$ 121,200$.

Table 25 .

Externship program costs and unit-based orientation extension cost for the study sample:

\begin{tabular}{ccc}
\hline & Extern Experience & No Extern Experience \\
\hline Extern salary $(\$ 4,200 * 20)$ & $\$ 84,000.00$ & $\$ 0$ \\
RN preceptor differential $(300 * 20)$ & $\$ 6,000.00$ & $\$ 0$ \\
Extension of orientation & $\$ 28,160.00$ & $\$ 239,360.00$ \\
\hline Total cost & $\$ 118,160.00$ & $\$ 239,360.00$ \\
\hline
\end{tabular}

Note. Cost of the extern program and extension of orientation for both former externs and nonexterns.

The ROI process model (Buzachero, Phillips, Phillips, \& Phillips, 2013; Phillips, 2007) used as a framework for this study includes a formula used to determine the monetary return on investment of the educational program. According to the formula, the ROI can be computed by 
dividing net program benefits by the net program cost and multiplying the result by 100 thus resulting into a percentage.

The program benefit to the organization hinges on the less frequency of unit-based orientation extension of the externs in the sample. The cost of orientation extension for the nonextern is $\$ 239,360$. The cost for orientation extension for the former extern is $\$ 28,160$. The difference is $\$ 211,200$ in cost savings or cost benefit. The cost of the externship program for 20 participants is $\$ 90,000$ and thus the net benefit (benefit minus cost) is equal to $\$ 121,200$.

Thus the ROI for this program can be calculated by dividing the net program benefits of $(\$ 211,200-\$ 90,000)$ by $\$ 90,000$ and multiplying the result by 100

$$
\begin{aligned}
& =\$ 211,200-\$ 90,000 / \$ 90,000 \times 100 \\
& =\$ 121,000 / \$ 90,000 \times 100 \\
& =1.35 \times 100 \\
& =135 \%
\end{aligned}
$$

Intangible benefits are included in the ROI formulas thus are listed however are not within the scope of this study. The intangible benefits associated with not extending the unit based orientation include: less anxiety and discouragement on the part of the new grad RN and less frustration on the part of the preceptor and peers. The long-term outcome variables listed in the earlier formulas were not included in the final formula because correlations of the variables were not demonstrated through the statistical analysis. 


\section{Figure 3. Foci of research study}

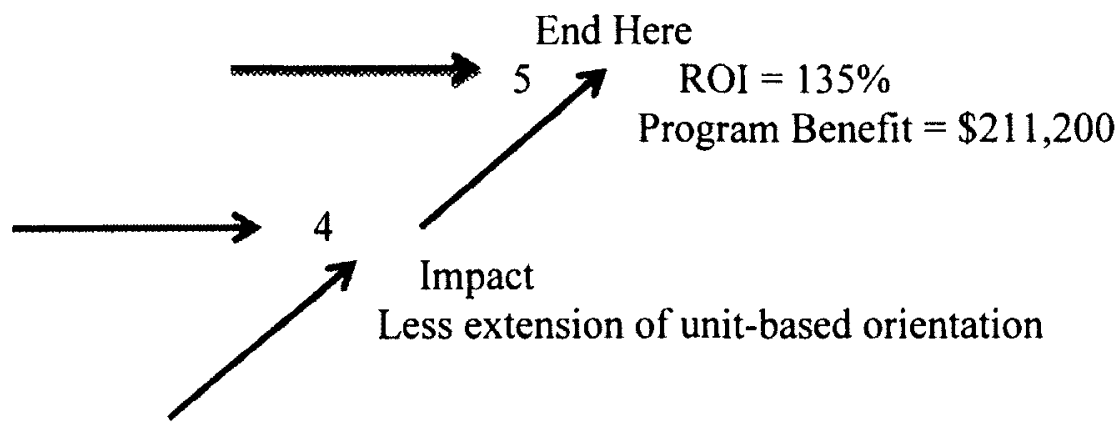

Figure 3. The two areas of focus of the research study include the project impact or level 4 and ROI or level 5 of the measurement and evaluation phase of the ROI process model.

This study, similar to earlier cited studies (Cantrell \& Browne, 2006; Lott et al., 2011; Pine \& Tart, 2007), showed immediate impact of the externship program during the initial employment phase of a new registered nurse. In this study a closer look into the cost involved in orienting newly graduate RNs revealed an average of 100 hours of unit-based orientation extension. The cost of orientation extension is amplified because non-extern RNs tend to extend orientation more than former externs and a larger number of them are hired as newly graduate RNs compared to former externs.

Although the organization at which this retrospective study took place has a $1 \%$ to $3 \% 2$ year turnover rate for newly graduate nurses, turnover occurs after 2 years of employment and for this matter, after the organization has invested heavily in an extensive new grad $\mathrm{RN}$ training in the form of the MAP program and unit-based orientation. Although the turnover rate and timeframe has improved markedly after the establishment of the MAP Program in 2005, much work is needed to improve the overall turnover rate of the organization. 
A review of the summary of the organization's exit interviews with RNs revealed the most cited reason for leaving the organization is pay practice but much can be attributed to the atmosphere of one's work environment. Decades worth of extensive literature has shown the high retention and low turnover rates in American Nurses Credentialing Center (ANCC) Magnet $^{\mathrm{TM}}$ designated facilities. The facilities included in this project are not Magnet-designated and thus it would be beneficial to conduct a similar but longitudinal study in an ANCC Magnetdesignated institution.

The review of literature revealed the various externship program structures (Hoffart et al., 2011; Ruth-Sahd et al., 2010; Steen et al., 2011; Lott et al., 2011; Pine \& Tart, 2007). Elements of each structure can be used to develop one that fits the strategic goals of each organization. Both short-term and long-term goals need to be identified when developing the program along with evaluation processes including a complete return on investment formula.

Limitations of the study. A few limitations of this study are important to note. Little is known about the impact of the workplace on new nurses during the first 5 years of their employment. The workplace may have influenced the participants' decisions regarding their employment, termination, transfer, and adherence to core measures.

Preceptors are also markedly influential (Marks-Maran et al., 2012). Although all the RNs within the organization receive preceptor training prior to receiving preceptor benefits, their personal communication and teaching styles vary thus producing a wide variety of preceptor experiences for the newly graduate nurse. The great majority of the nursing staff received preceptor training but there are a few who have not had the opportunity to participate in the training thus leading to inconsistencies in the new grad orientation experience. 
The choice of adherence to core measures as a quality outcome also has its limitation. Core measures were introduced to the organization in 2011. By that time, study participants had already left the organization and were never responsible for meeting the measures. Additionally, core measures are specific to service lines and thus not all participants were responsible for core measures. Even with mandatory staff in-services, the novelty of core measures brought about a learning curve leading to non-adherence or lack of documentation of adherence.

Implications of the study. The findings and contribution of the study to existing literature include both the short term and long term impact of the externship program and is applicable to the nursing practice setting. The short term impact findings include nurses with extern experience extend orientation less than nurses with no externship experience and the average extension of unit-based orientation is 100 hours per new nurse. The long-term impact findings include there is no significance between the between nurses with extern experience and those without in relation to long-term employment and adherence to documentation of core measures. The results of this study can be used in making decisions regarding the implementation and continuous sustenance of not only extern programs but also post-licensure residency programs in the hospital settings (Anderson, Hair, \& Todero, 2012; Goode, Lynn, Krsek, \& Bednash, 2009).

Academic settings can use the findings from this study to describe the positive impact of the program to the students' transition into their professional role and the financial impact to the hospital. The findings lead to the need to investigate and understand how preceptors are trained (Marks-Maran et al., 2012) and recognized in the practice setting along with the importance of unit-based education in addressing the learning curve related to new initiatives such as quality indicators. 
More research is needed in this area to continue to understand the effects of the practice environment in decision-making, clinical judgment and intent to stay, all of which effect the work environment of nurses and patient safety and is of interest to hospital administrators. Sites for future research can include ANCC Magnet ${ }^{\mathrm{TM}}$ and Pathway to Excellence ${ }^{\mathrm{TM}}$ designated hospitals known to have high retention rates in the short term. The body of literature would benefit from the results of longitudinal studies using both quantitative and qualitative methodology. When choosing quality indicators, correlate unit-based quality indicators impact with the nurses practicing in areas at the units in which the quality indicators are relevant. Intangible factors also need to be examined. 


\section{References}

Anderson, G., Hair, C., \& Todero, C. (2012, July-August). Nurse residency programs: An evidence-based review of theory, process, and outcomes. Journal of Professional Nursing, 28(4), 203-212.

Bates, T., \& Dower, C. (2010). California nurses facts and figures. Retrieved from http://www.chcf.org/publications/2010/11/california-nurses-facts-and-figures

Beecroft, P. C., Dorey, F., \& Wenten, M. (2008). Turnover intention in new graduate nurses: A multivariate analysis. Journal of Advanced Nursing, 62(1), 41-52.

Beecroft, P. C., Kunzman, L., \& Krozek, C. (2001, December). RN internship. Outcomes of a one-year pilot program. Journal of Nursing Administration, 3l(12), 575-582.

Bielanski, G. (2009). Practical guide to core measures improvement. Marblehead, MA: HCPro.

Bozeman, B., \& Feeney, M. K. (2007). Toward a useful theory of mentoring: A conceptual analysis and critique. Administration \& Society, 39(6), 719-739.

Buerhaus, P. I., Auerbach, D. I., \& Staiger, D. O. (2009, June 12). The recent surge in nurse employment: Causes and implications (Web Exclusive). Health Affairs, 28(4), w657w668. http://dx.doi.org/10.1377/hlthaff.28.4w657

Buzachero, V. V., Phillips, J., Phillips, P. P., \& Phillips, Z. L. (2013). Measuring ROI in healthcare. New York: NY: McGraw-Hill.

Cantrell, M., \& Browne, A. (2005, November 1). The impact of a nurse externship program on the transition process from graduate to registered nurse. Part II. Qualitative findings. Journal for Nurses in Staff Development, 21(6), 249-256. 
Cantrell, M., \& Browne, A. (2006, January 1). The impact of a nurse externship program on the transition process from graduate nurse to registered nurse. Part III. Recruitment and retention effects. Journal for Nurses in Staff Development, 22(1), 11-14.

Cantrell, M., Browne, A., \& Lupinacci, P. (2005, September 1). The impact of a nurse externship program on the transition process from graduate to registered nurse. Part I. Quantitative findings. Journal for Nurses in Staff Development, 21(5), 187-195.

Centers for Medicare \& Medicaid Services. (n.d.). http://www.cms.gov/about$\mathrm{cms} /$ aca/affordable-care-act-in-action-at-cms.html

DelBueno, D. (2005, September/October). A crisis in critical thinking. Nursing Education Perspectives, 26(5), 278-282.

Flower, J. (2013). Healthcare beyond reform, Doing it right for half the cost. Boca Raton, FL: CRC Press.

Goode, C., Lynn, M., Krsek, C., \& Bednash, G. (2009, May-June). Nurse residency programs: An essential requirement for nursing. Journal of Nursing Economic\$, 27(3), 142-147, 159.

Hoffart, N., Waddell, A., \& Young, M. (2011, November-December). A model of new nurse transition. Journal of Professional Nursing, 27(6), 334-343.

Kilpatrick, K., \& Frunchak, V. (2006). The nursing extern program. Innovative strategies for students in transition. The Health Care Manager, 25(3), 236-242.

Kirkpatrick, D. A. (1998). Evaluating Training Programs: The Four Levels. San Francisco: Bennett. 
Lott, T., Willis, L., \& Lyttle, E. (2011, November 1). The successful redesign of a student nurse extern program. Journal of Nurses in Staff Development, 27(5), 236-239. http://dx.doi.org/doi:10.1097/NND.0b13e31822d6fl4

Makary, M. (2012). Unaccountable, What hospitals won't tell you and how transparency can revolutionize health care. New York, NY: Bloomsbury Press.

Marks-Maran, D., Ooms, A., Tapping, J., Muer, J., Phillips, S., \& Burke, L. (2012). A preceptorship programme for newly qualified nurses: A study of preceptees' perception. Nurse Education Today. http://dx.doi.org/http://dx.doi.org/http://dx.doi.org/10.1016/j.nedt.2012.11.013

National Council of States Boards of Nursing. (2009). Report of findings from the post-entry competence study (Research Brief Vol.8). Retrieved from https://www.ncsbn.org/2897.htm

Performance Management Services, Inc. (n.d.). http://www.pmsi-pbds.com Phillips, J. J. (1977, October). Is cooperative education worth it? One company's answer. Personnel Journal, 505-507.

Phillips, J. J., Brantley, W., \& Phillips, P. P. (2011). Project Management ROI: A Step-by-Step Guide for Measuring the Impact of ROI for Projects. NJ, USA: Wiley.

Phillips, J. J., \& Phillips, P. P. (2007). Show Me the Money. How to Determine the ROI in People, Projects, and Programs (2 ed.). San Francisco, CA: Berrett-Koehler.

Pine, R., \& Tart, K. (2007, January/February). Return on investment: Benefits and challenges of a baccalaureate nurse residency program. Nursing Economic\$, 25(1), 13-18, 39. http://dx.doi.org/Retrieved from 
Rush, K. L., Adamack, M., Gordon, J., Lilly, M., \& Janke, R. (2013). Best practices of formal new graduate nurse transition programs: An integrative review. International Journal of Nursing Studies, 50, 345-356.

http://dx.doi.org/http://dx.doi.org/http://dx.doi.org/10.1016/j.ijnurstu.2012.06.009

Ruth-Sahd, L. A., Beck, J., \& McCall, C. (2010, March/April). Transformative learning during a nursing externship program: The reflections of senior nursing students. Nursing Education Perspectives, 3l(2), 78-83.

Stanley, J. M., Gannon, J., Gabuat, J., Hartranft, S., Adams, N., Mayes, C., ... Burch, D. (2008). The clinical nurse leader: A catalyst for improving quality and patient safety. Journal of Nursing Management, 16, 614-622.

Starr, K., \& Conley, V. M. (2006, July/August). Becoming a registered nurse: The nurse extern experience. The Journal of Continuing Education in Nursing, 86-92.

Steen, J., Gould, E., Reingruber, B., \& Hill, J. (2011, July/August). Effect of student nurse intern position on ease of transition from student nurse to registered nurse. Journal for Nurses in Staff Development, 27(4), 181-186.

Stinson, S., \& Wilkinson, C. (2004, May/June). Creating a successful clinical extern program using a program planning logic model. Journal for Nurses in Staff Development, 20(3), 140-144.

Ulrich, B., Krozeck, C., Early, S., Ashlock, C. H., Africa, L. M., \& Carmen, M. L. (2010, November/December). Improving retention, confidence, and competence in new graduate nurses: Results from a 10-year longitudinal data base. Nursing Economic\$, 28(6), 363375. 
Appendix A

List of core measures

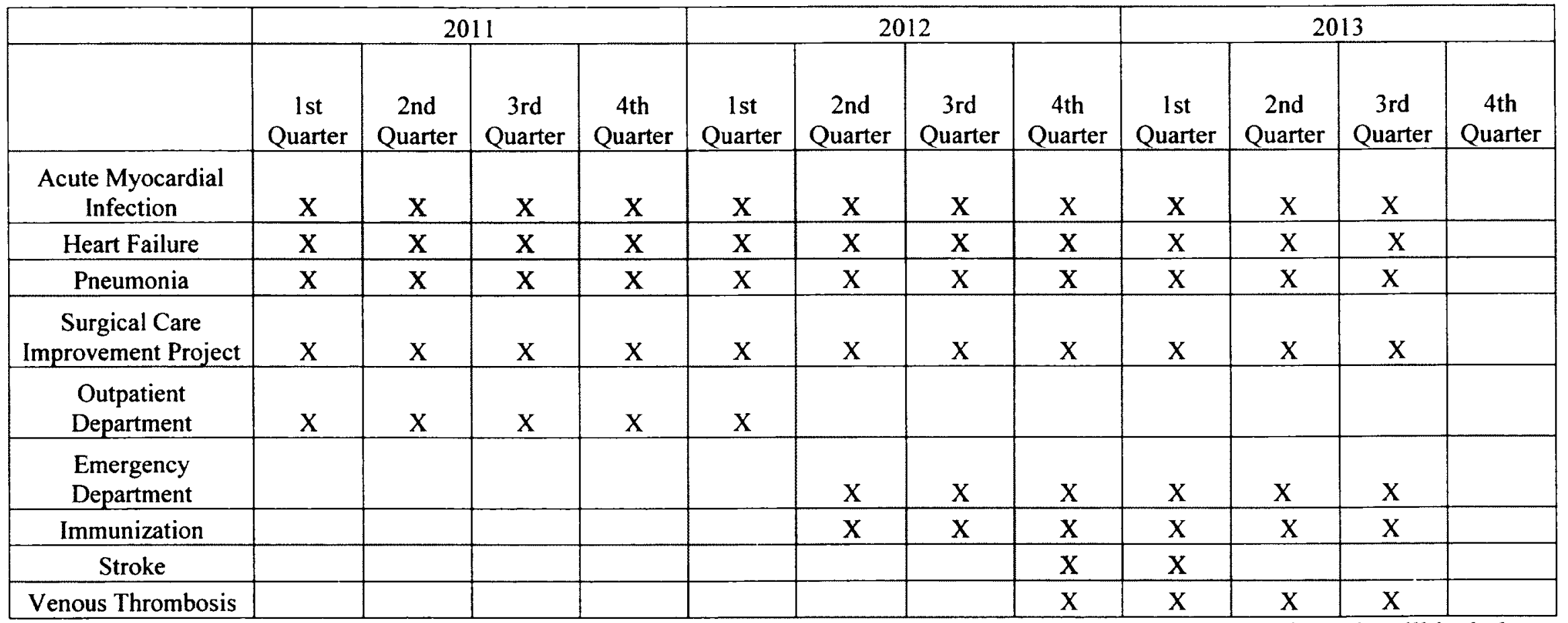

Note. The first column lists the title of core measures. The $\mathrm{X}$ denotes the months the measures were reported. This study will include the reports submitted up until the third quarter of 2013. 
APPENDIX B

DATA COLLECTION TOOL 
Appendix B. Data collection tool

\begin{tabular}{|c|c|c|c|c|c|c|c|c|c|c|c|c|c|}
\hline \multicolumn{14}{|c|}{ DATA COLLECTION TOOL } \\
\hline & Name & Employee \# & Age & $\begin{array}{l}\text { Number of } \\
\text { hours } \\
\text { worked as } \\
\text { extern }\end{array}$ & $\begin{array}{l}\text { Cost center } \\
\text { employed as } \\
\text { a new grad }\end{array}$ & $\begin{array}{l}\text { Number of } \\
\text { hours of } \\
\text { orientation as } \\
\text { new grad }\end{array}$ & $\begin{array}{l}\text { Number of } \\
\text { hours of } \\
\text { average } \\
\text { orientation }\end{array}$ & $\begin{array}{l}\text { Number of } \\
\text { hours beyond } \\
\text { average } \\
\text { orientation }\end{array}$ & $\begin{array}{c}\text { Extended } \\
\text { Orientation }\end{array}$ & $\begin{array}{l}\text { Number of hours } \\
\text { during first } 5 \\
\text { years of } \\
\text { employment }\end{array}$ & $\begin{array}{l}\text { Leave of } \\
\text { Absence }\end{array}$ & $\begin{array}{l}\text { Full time } \\
\text { employment } \\
\text { over first } \\
\text { 5years? }\end{array}$ & $\begin{array}{l}\text { Inclusion in } \\
\text { fall out } \\
\text { report }\end{array}$ \\
\hline 1 & & & & & & & & & & & & & \\
\hline 2 & & & & & & & & & & & & & \\
\hline 3 & & & & & & & & & & & & & \\
\hline 4 & & & & & & & & & & & & & \\
\hline 5 & & & & & & & & & & & & & \\
\hline 6 & & & & & & & & & & & & & \\
\hline 7 & & & & & & & & & & & & & \\
\hline 8 & & & & & & & & & & & & & \\
\hline 9 & & & & & & & & & & & & & \\
\hline 10 & & & & & & & & & & & & & \\
\hline 11 & & & & & & & & & & & & & \\
\hline 12 & & & & & & & & & & & & & \\
\hline 13 & & & & & & & & & & & & & \\
\hline 14 & & & & & & & & & & & & & \\
\hline 15 & & & & & & & & & & & & & \\
\hline 16 & & & & & & & & & & & & & \\
\hline 17 & & & & & & & & & & & & & \\
\hline 18 & & & & & & & & & & & & & \\
\hline 19 & & & & & & & & & & & & & \\
\hline 20 & & & & & & & & & & & & & \\
\hline
\end{tabular}

